\title{
Faults and fractures in central West Greenland: onshore expression of continental break-up and sea-floor spreading in the Labrador - Baffin Bay Sea
}

Robert W.W ilson, Knud Erik S. K lint, Jeroen A.M. van G ool, Kenneth J.W. M cC affrey, Robert E. Holdsworth and James A. Chalmers

The complex Ungava fault zone lies in the $D$ avis Strait and separates failed spreading centres in the Labrador Sea and Baffin Bay. This study focuses on coastal exposures east of the fault-bound Sisimiut basin, where the on shore expressions of these fault systems and the influence of pre-existing basement are examined. Regional lineament studies identify five main systems: $\mathrm{N}-\mathrm{S}, \mathrm{N} N \mathrm{~N}$-SSW, EN E-W SW, ESE-W N W and N N W-SSE. Field studies reveal that strike-slip movements predominate, and are consistent with a N N E-SSW-oriented sinistral wrench system. Extensional faults trending N - S and EN E-W SW (basement-parallel), and compressional faults trending E-W, were al so identified. The relative ages of these fault systems have been interpreted using cross-cutting relationships and by correlation with previously identified structures. A two-phase model for fault development fits the devel opment of both the onshore fault systems observed in this study and regional tectonic structures offshore. The conclusions from this study show that the fault patterns and sense of movement on faults onshore reflect the stress fields that govern the opening of the Labrador Sea - D avis Strait Baffin Bay seaway, and that the wrench couple on the Ungava transform system played a dominant role in the development of the onshore fault patterns.

Keywords: faults and fractures, extensional tectonics, wrench systems, sedimentary basins, basement reactivation, West Greenland

\begin{abstract}
R.W.W., K.J.W.M . \& R.E.H ., Reactivation Research G roup, D epartment of Earth Sciences, U niversity of D urham, D urham DH 1 3LE, UK. E-mail: robert.wilson@durham.ac.uk

K.E.S.K., J.A.M .v.G. \& J.A.C., G eological Survey of D enmark and G reenland, Ø ster Voldgade 10, D K-1350 Copenhagen K, D enmark.
\end{abstract}

\section{Introduction}

Pre-existing heterogeneities in the continental crust, such as shear zones and terrain boundaries, have long been known to influencethe structureand development of later deformation events (Butler et al. 1997; H oldsworth et al. 1997, and references therein). The sedimentary basins of the Labrador Sea - Baffin Bay region are situated west of Greenland (Fig. 1) and are early C enozoic failed spreading centres (C halmers \& Pulvertaft 2001), separated by the $D$ avis Strait. Theorientation of the $D$ avis Strait relativeto the proposed spreading centres in the Labrador Sea and Baffin Bay is consistent with the geometry of an 'extensional transform zone' (Taylor et al. 1994). Steep basement fabrics of the N agssugtogidian orogen trend highly obliquely to these offshore structures (Fig. 1) and coincide with this 'step-over zone' in the Davis Strait. Fault systems fundamental to the development of sedimentary basins in the $D$ avis Strait are exposed onshore in West $G$ reenland. In this project, the onshore fault systems of central West Greenland were studied in order to improve 


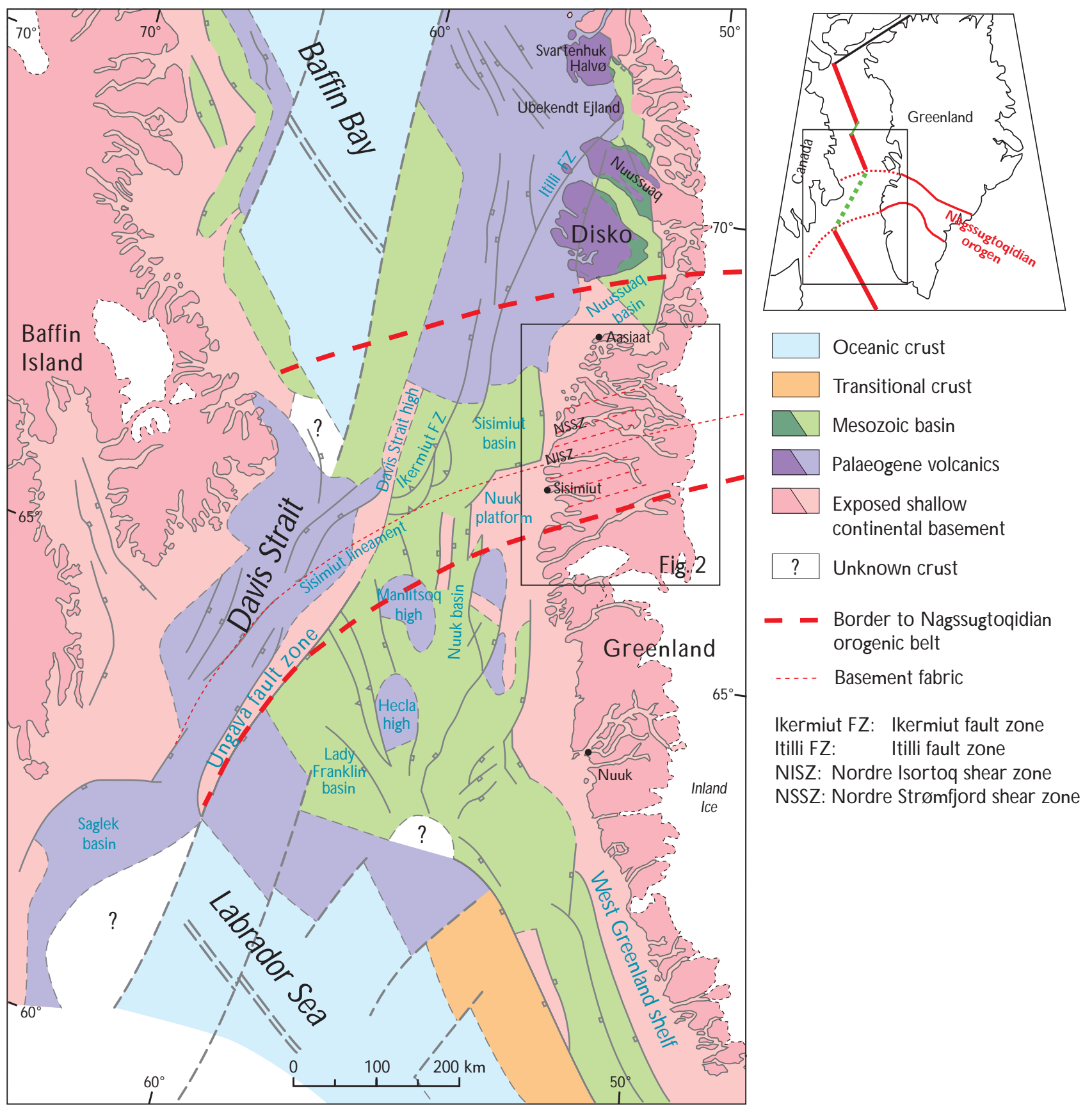

Fig. 1. Regional tectonic map of the offshore geology of the Labrador Sea - Baffin Bay area between Canada and Greenland. M odified from Chalmers \& Pulvertaft (2001).

Facing page:

Fig. 2. Geological map of the $N$ agssugtogidian orogen of central West G reenland (modified from Escher \& Pulvertaft 1995). A: 0 utline map of Greenland highlighting the region covered in Fig. 2B. B: Geological map of the N agssugtogidian orogen showing main lithological units and basement structures. C: Topographic contour map of the central coastal area showing the field camps chosen for this study (camps 0 to 4); black dashed lines highlight major topographic escarpments. D: 3-D model view of N NE-trending coastal escarpment, constructed in ArcG IS by draping a Landsat image onto a topographic model. Abbreviations used: SN $\mathbf{O}$, CN $\mathbf{O}$ and $\mathbf{N} \mathbf{N} \mathbf{O}$ are the southern, central and northern N agssugtoqidian orogen, respectively. ITZ, I kertôq thrust zone; N ISZ, N ordre I sortoq shear zone; N SSZ, N ordre Strømfjord shear zone. 


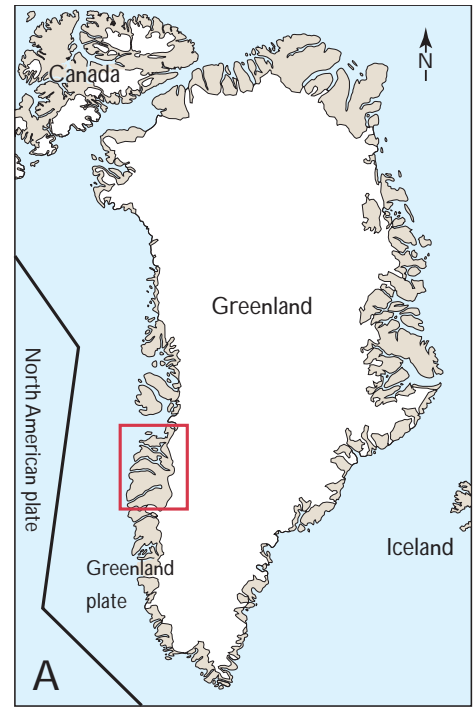

Surficial Q uaternary deposits

PROTERO ZO IC

Calc-alkaline intrusions Arfersiorfik and Sisimiut suites

Granitic intrusions

Metasedimentary rocks

Archaean gneisses reworked in the Palaeoproterozoic

\section{ARCHAEAN}

Supracrustal rocks

Metasedimentary rocks

Anorthosite and ultrabasic rocks

Granitic intrusions

0 rthogneisses

Thrusts

„_- Basement fabrics

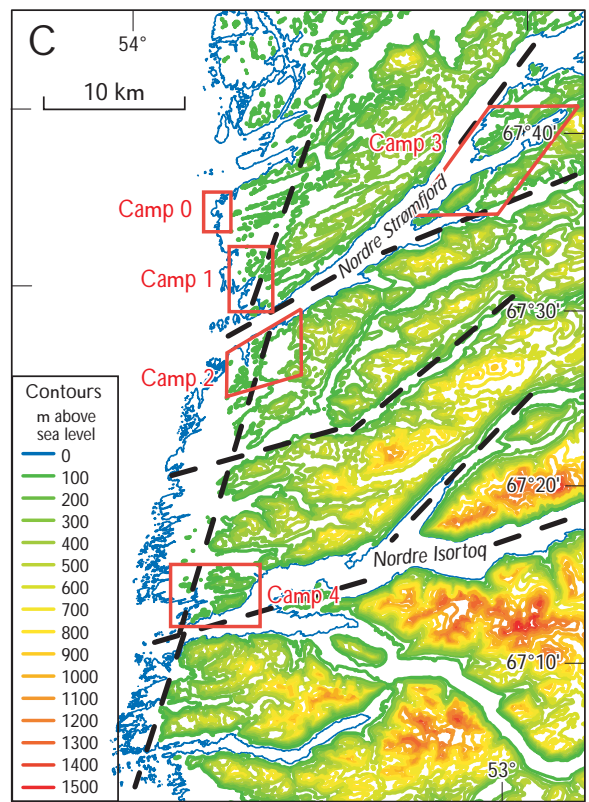

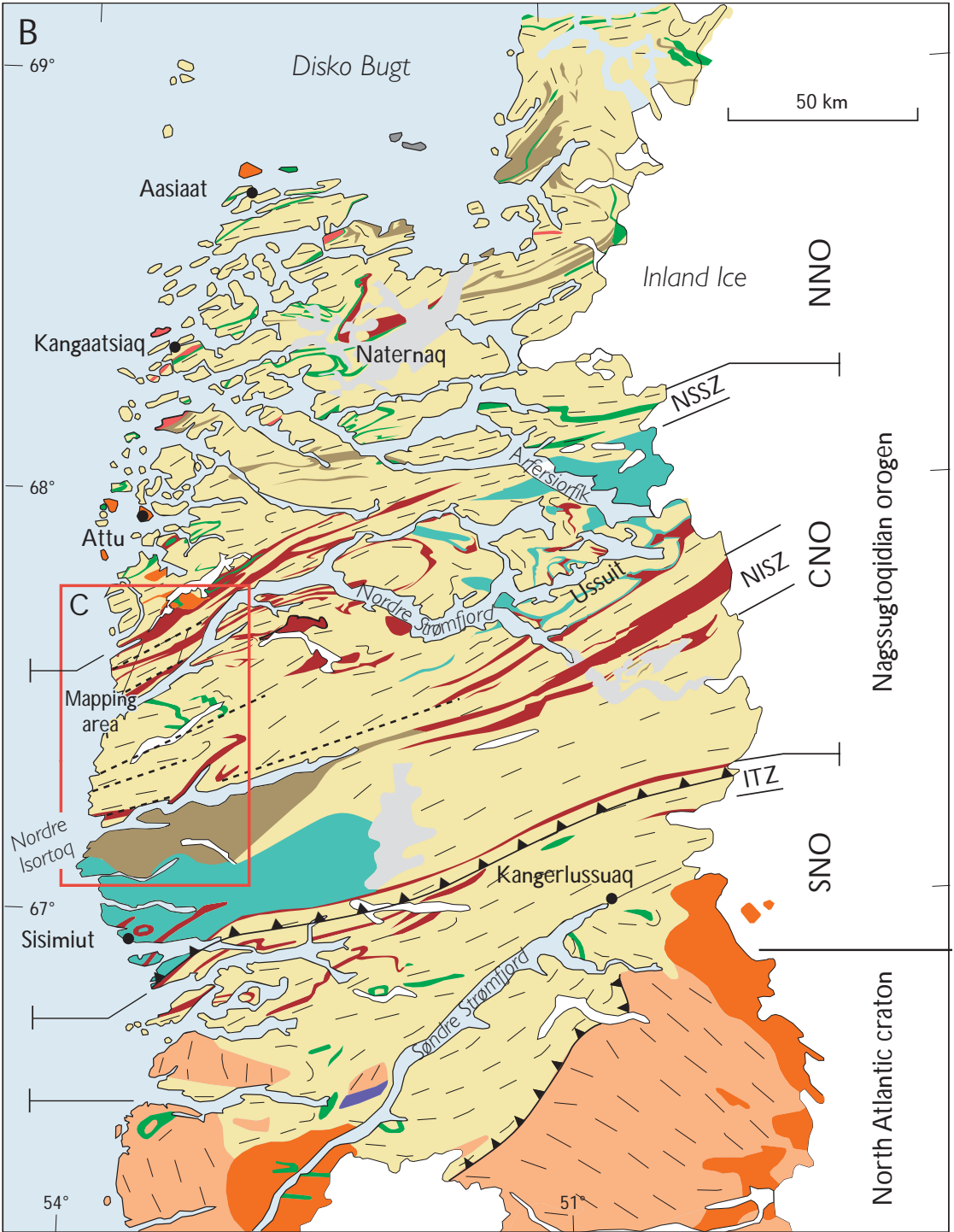

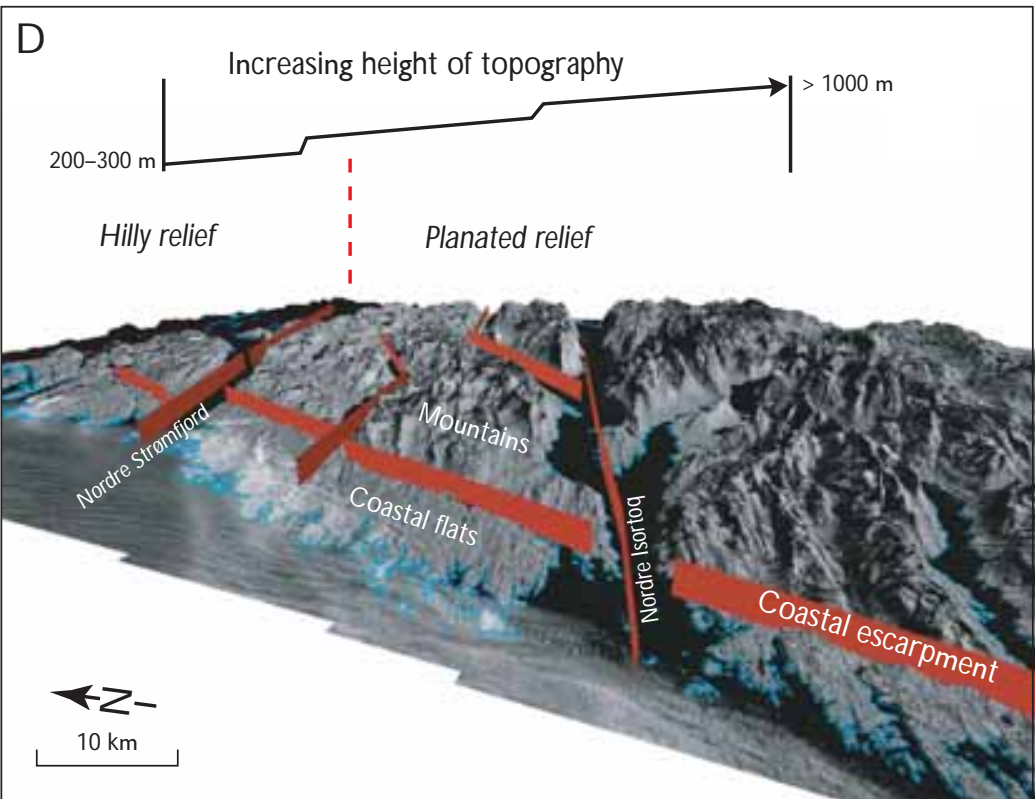


the understanding of the role played by basement reactivation in offshore basin development.

In the summer of 2003 field work was carried out in an area along the coast stretching from N ordre Strømfjord (N assuttooq) in the north, to N ordre I sortoq in the south (Figs 2, 3). This area was selected because it is believed that two ENE-striking Palaeoproterozoic shear zones, the N ordre Strømfjord shear zone and the N ordre I sortoq shear zone, were reactivated and played an important role in the development of the M esozoic to Tertiary sedimentary basins. The western projection of the N ordre I sortoq shear zone appears to coincide with the southern faulted boundary of theSisimiut basin offshore (Figs 1, 2). In addition, the offshore basins occur close to the coast in this area, and the offshore extensional faults that drop the top of the basement down to $3 \mathrm{~km}$ bel ow sea level, within $10 \mathrm{~km}$ west of the coast, are believed to correlate with fault escarpments onshore in this area.

\section{Tectonic and geological setting}

\section{O ffshore}

The Labrador Sea and Baffin Bay formed during divergent platemotion between $\mathrm{G}$ reenland and N orth America during the early Cenozoic (C halmers \& Pulvertaft 2001, and referencestherein). Theextensional basinsof Baffin Bay and the Labrador Sea are separated by a bathymetric high in the $D$ avis Strait (Fig. 1). This transverse ridge is interpreted as a complex sinistral-shear transform fault zone, known as the U ngava fault system (Fig. 1; C halmers et al. 1995). Extensional faulting and tectonic subsidence are thought to have commenced in the early Cretaceous, at the same time as sea-floor spreading in the N orth Atlantic south of the $C$ harlie G ibbs fracture zone. O pening started during the Pal eocene (C hian \& Louden 1994; C halmers \& L aursen 1995), and sea-floor spreading appears to have ceased by the 0 ligocene.

Interpretation of seismic reflection data has revealed the existence of a number of sedimentary basins offshore western Greenland (C halmers et al. 1995; W hittaker 1995). O ne such basin is the deep Sisimiut basin, located in the $D$ avis Strait to the west of the N ordre Strømfjord region (Fig. 1). At about $10 \mathrm{~km}$ west of the coast, the top of the basement is at c. $3 \mathrm{~km}$ depth, while there is no cover preserved on top of basement exposed onshore. Therefore, the eastern border of the basin must bea major fault, but it is located too close to the coast to have been surveyed by a seismic experiment. The orientation of this bounding fault is likely to follow the N N E-SSW trend of the coastline. The western margin of the Sisimiut basin is the N N E-SSW-trending Ikermiut fault zone (Fig. 1), a transpressional flower structure developed along thetransform fault (U ngava fault zone) between the $\mathrm{N}$ orth American and G reenland plates (Fig. 2) formed during the Palaeogene (i.e. it cuts early Eocene strata; C halmers \& Pulvertaft 2001). TheN ukik platform lies to the south of the Sisimiut basin and is separated from it by a line of ENEand $\mathrm{E}$-trending faults that coincide with the offshore extension of the N ordre Isortoq shear zone onshore (Figs $1,2)$. It has therefore been proposed that the faults at the southern margin of thebasin devel oped by reactivation of basement shear zone structures in the central N agssugtoqidian orogen. Thesefaults affect M esozoic sediments and are overstepped by Paleocene sediments, so that the latest significant movement on them must have been prior to the end of the Paleocene.

\section{O nshore}

O nshoreexposuresin central W estG reenland, from Søndre Strømfjord in the south to D isko Bugt in the north, comprise high-grade gneisses of the Palaeoproterozoic N agssugtogidian orogen (Fig. 2; Ramberg 1949; van Gool et al. 2002). The N agssugtogidian orogen is a $300 \mathrm{~km}$ wide belt of predominantlyA rchaean orthogneisses, Palaeoproterozoic paragneissesand intrusive rocks, that were reworked during Palaeoproterozoic orogenesis (van Gool et al. 2002). These basement rocks form EN E-trending linear belts of steeply dipping gneisses, some of which are crustal-scale shear zones (i.e. the Nordre Strømfjord and $\mathrm{N}$ ordre Isortoq shear zones, Fig. 2), which alternate with zones dominated by kilometre-scale fold structures (van $\mathrm{G}$ ool et al. 2002). T he N agssugtogidian orogen is divided into three tectonic segments: the southern, central and northern N agssugtogidian orogen (Fig. 2; $\mathrm{M}$ arker et al. 1995). T heonshore research in this study lies entirely within the granulite facies orthogneisses of the central $\mathrm{N}$ agssugtogidian orogen, which is bound to the north by the

\section{Facing page:}

Fig. 3. Lineament map of the main study area derived from lineament mapping of a Landsat TM image at 1:100 000 scale (total 1284 lineaments), using ArcGIS. The main rose diagram (bottom right) shows the distribution of lineaments for this map, while smaller rose diagrams (left) show results from aerial photograph analyses (at 1:20 000 scale) for each field camp. G reen, system 1; blue, system 2; red, system 3; yellow, system 4; purple, system 5 . Red box shows the position of Fig. 4. 


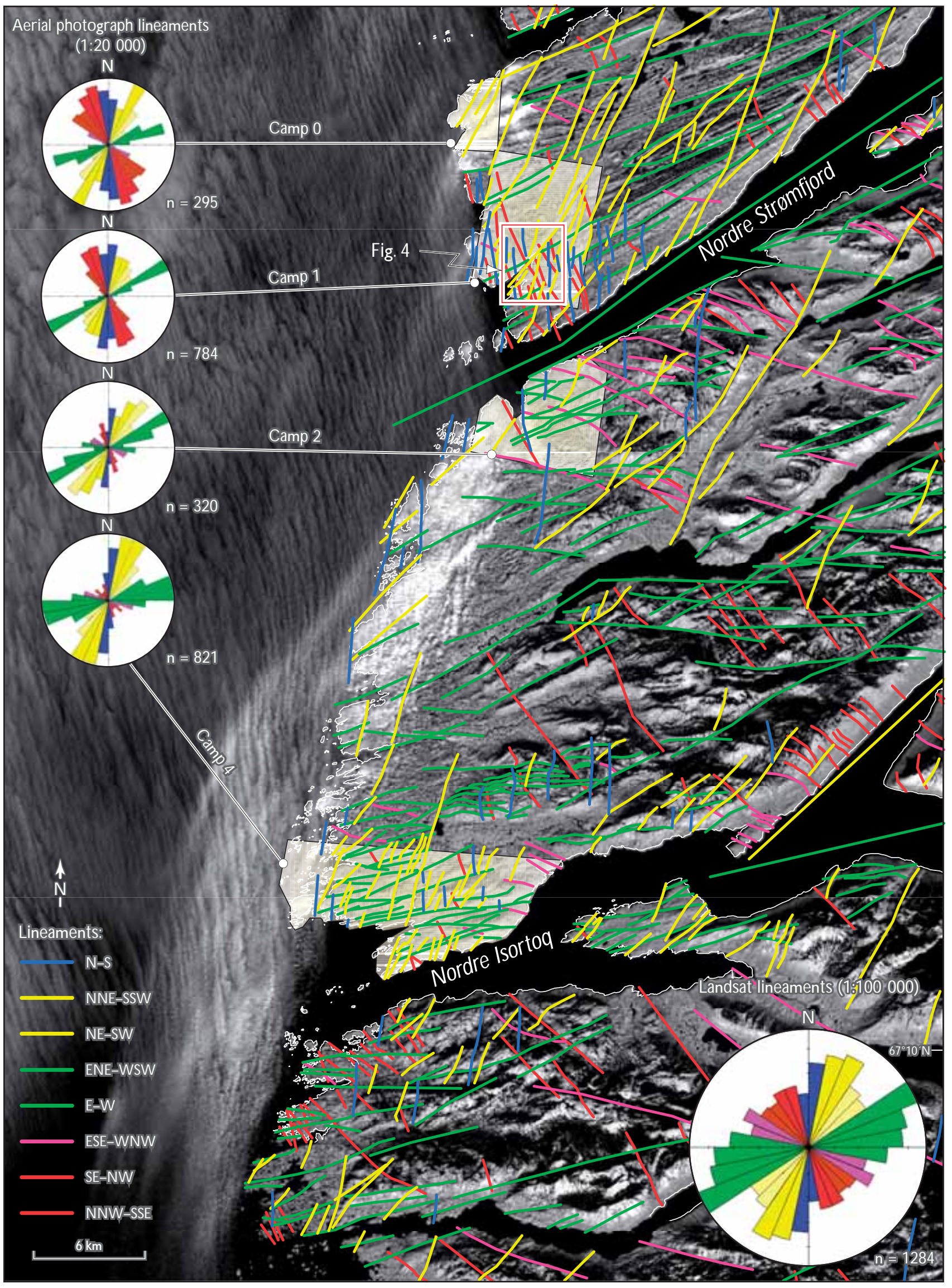


N ordre Strømfjord shear zone (M arker et al. 1995; van Gool et al. 2002) and to the south by the I kertôq thrust zone (Fig. 2).

Indirect topographic evidence from geomorphological investigations has suggested that late (M esozoic or C enozoic) onshore fault movements may haveoccurred (Bonow 2004). For example, in some of the larger inlets and valleys, characteristicrecent shellymarinesands can beobserved up to $30 \mathrm{~m}$ above sea level. These are likely to have been uplifted due to isostatic rebound following glacial retreat. H owever, variations in elevation of these palaeoshorelines may also result from differential vertical fault movements or differential unloading. $\mathrm{O}$ the larger scale, the N ordre Strømfjord shear zone marks a major change between two landscape types (Japsen et al. 2002). South of the N ordre Strømfjord shear zone topography is planated, with flat mountain tops forming a plateau that gradually increases in height southwards from 500 to $1000 \mathrm{~m}$ (Fig. 2C, D). In contrast, north of the N ordre Strømfjord shear zone, the land has a hilly relief with a relatively flat and lowlying topography with isolated hills up to $300 \mathrm{~m}$ high. Locally, the changein landscape type occurs across a more than $500 \mathrm{~m}$ high, EN E-W SW-oriented escarpment that drops down to the north (Fig. 2).

There is al so a pronounced N N E-SSW -oriented escarpment almost $1 \mathrm{~km}$ high that drops down to the west between N ordre Strømfjord and N ordre Isortoq (Fig. 2). This major escarpment separates low-lying (50-150 m high) coastal flats to the west from the much higher (500 $\mathrm{m+}$ ) mountains to the east (Fig. 2) and can be traced for over $80 \mathrm{~km}$, from Sisimiut in the south to N ordreStrømfjord in the north. Similar escarpments can be observed in the near offshore on both bathymetric and horizon maps of depth to basement, thus supporting the theory that onshore structures reflect those offshore.

\section{Methods}

The present study combines regional to outcrop-scale mapping and regional studies of remotely sensed data to determine fault-fracture geometries, distribution, relative timing and kinematics in selected key areas of central West Greenland.

Regional studies comprised satellite image and aerial photograph analysisat a variety of scales (1:500 000; 1:100 000; 1:20 000) in order to identify lineaments and other geological structures (e.g. variations in lithology, fabric intensity, faults, fractures).

Field investigations were carried out in the well-exposed Precambrian basement rocks in key areas of interest that were identified during aerial photograph analysis prior to departure. A number of field camps were used during the mapping (Fig. 2C). C amp 0 was located at I nussuk, a site visited previously in 2002 (Japsen et al. 2002). Camps 1 and 2 were located on the north and south shores of $\mathrm{N}$ ordre Strømfjord, while camp was on the north shore of N ordre Isortoq. C amp 3 was farther inland, and is not analysed further in this study.

During field work, fault and fracture systems were mapped, and the following structural data were collected for statistical/structural analysis:

- Fault attributesincluding: orientation; kinematics; fault surface characteristics; mineralisation.

- Relative age relationships.

- Structural/statistical analyses to determine kinematic patterns.

0 ver 200 pseudotachylite and mica-bearing fault-rock samples were al so collected from different fault sets at various localities in order to date the fault movements using ${ }^{40} \mathrm{Ar} /{ }^{39} \mathrm{Ar}$ geochronology (results to be discussed el sewhere). All field data were geospatially located (to $5 \mathrm{~m}$ resolution) using G lobal Positioning System (GPS) waypoint collection, and were subsequently stored in a computer database with links to G eographic Information System (GIS) based maps.

\section{Fault and fracture characterisation}

Fractures include all brittle structures such as joints, fissures, cracks, veins, etc. that are not faults, bedding or cleavage surfaces, and are larger than the grain size of the rock. In general, fractures are defined as dominantly tensile (mode I) cracks, and as such, they are associated with characteristic stress, strain and displacement fields. They are distinguished from small faults by distinctive surface textures and lack of shear displacements. Faultsare mapped where distinct offsets have been identified, often with a development of slip striae on the surface (slickenlines). C riteria for determining the sense of movement were based on methods outlined in M cClay (1987) and Petit (1987).

In the present study faults were classified as:

- Normal (extensional dip / oblique-slip fault).

- Reverse (compressional dip / oblique-slip fault).

- Strike-slip faults (dextral or sinistral).

The classification of faults and fractures into systems was primarily based on the orientation of the structures (i.e. 
Fig. 4. Age relationships interpreted from cross-cutting relationships of lineament systems derived from aerial photographs for camp 1. Four dominant lineament trends are apparent: N-S (system 2), N NE-SSW (system 4), ENE-W SW (system 1), and N N W -SSE (system 3). Through crosscutting relationships a relative order of fault development is apparent, as indicated across the bottom of the image.

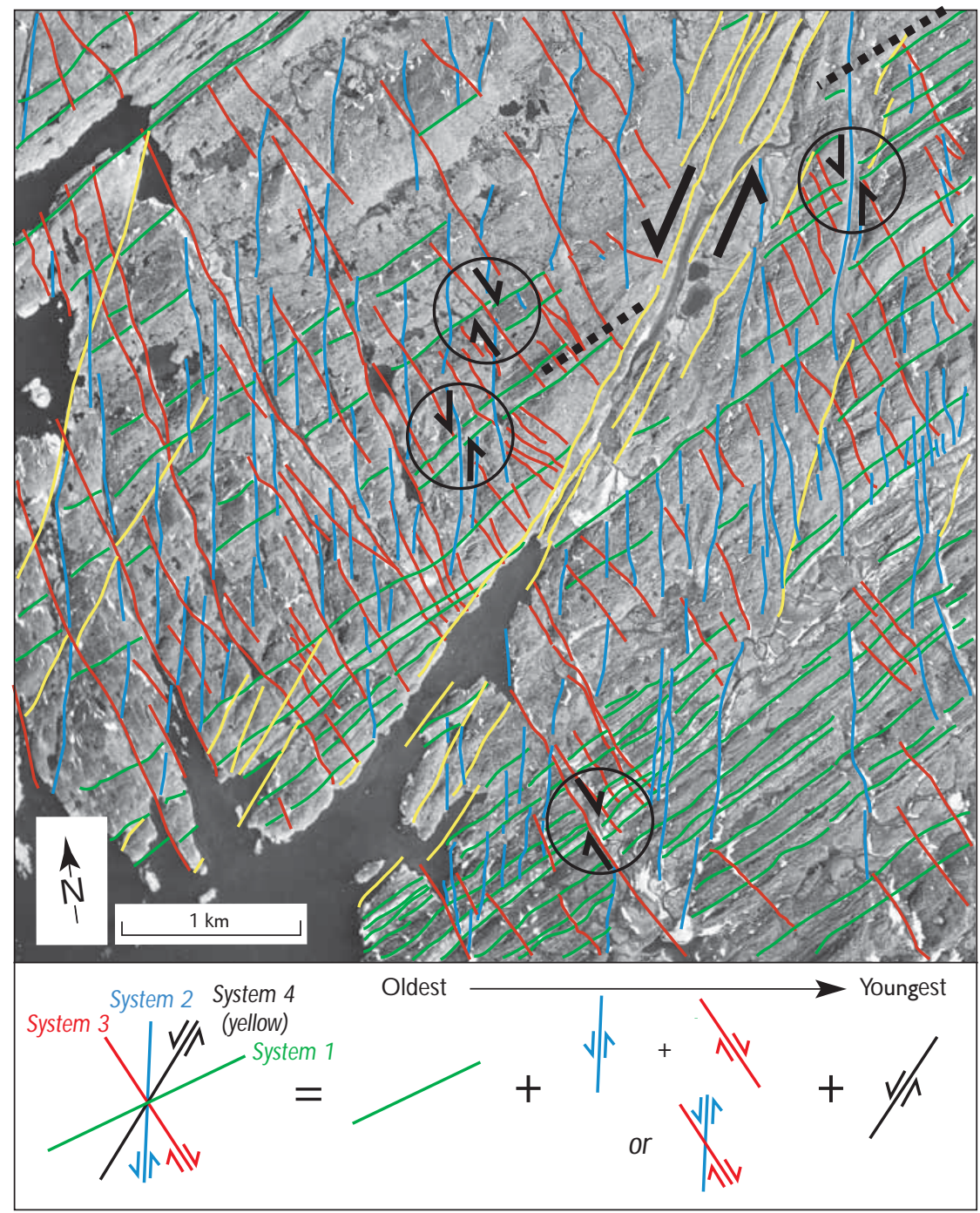

trend of lineament or strike of plane). Structures with different orientations can reflect different deformation phases, but in complexfault zonesdeveloped in three-dimensional (3-D) strain fields, multiple fault and fracture orientations may develop during a single event (see e.g. D e Paola et al. 2005). Therefore further classification needs to be applied, either through systematic fracture properties (such as surface type or mineralisation), or through kinematic studies, in order to determineif only one or several phases of deformation are apparent.

\section{Fault and fracture measurement technique}

In order to accurately classify the fault and fracture systems, populations of at least 50 fractures/faults weremeasured at most localities. Faults wereclassified according to type (normal/reverse dip-slip faults or dextral/sinistral strikeslip faults). Fault orientations and the directions of slickenlines (when observed) were measured, and the following characteristics recorded:

- Surface shape: The overall fracture shape (metre-scale) was described as listric, planar, undulating or irregular.

- Surface roughnesscharacter: The surface roughness character (millimetrescale) was described as smooth, rough or slickenside (striae)

- 0 ther features: Some fractures/faults have a filling of iron oxide precipitates, quartz crystals, epidote, or preferential growth of other crystals on the surface showing the slip direction. Special types of fractures such as conjugate shear fractures, en échelon fractures, plumose jointing etc. were noted if present. 


\section{Lineament mapping}

Lineament maps for the central Nagssugtogidian orogen (Fig. 3) were plotted from Landsat T M images and aerial photographsatavariety of scales (1:500000 and 1:100000 for Landsat images and 1:20 000 for aerial photographs). Images were georeferenced and displayed in a GIS environment and the lineaments picked by hand. After interpretation, lineaments were then refined using digital terrain model (DTM) analysis and compared to pre-existing geological maps of the region (e.g. H enriksen et al. 2000). As the data are stored in a GIS, attribute data for each lineament (i.e. trend; length; offset; otherfeatures) werealso measured orcal culated and stored. Spatial analysisand rose plotting toolsin ArcV iew G IS were used to analysetheorientation (Fig. 3) and spatial distribution of these structures.

A more detailed analysis of selected areas was then carried out at 1:20000 scale using aerial photographs. As image resolutions are much higher in aerial photographs ( $2 \mathrm{~m}$ pixel size), particular attention was paid to how the lineaments interact with topography (e.g. V-ing into valleys, etc.) to gain a better understanding of their overall geometry. G enerally all lineaments picked appear to have a steep dip as only minor interactions with topography were observed. Attention was also paid to cross-cutting relationships between lineaments in an attempt to determine the relative timing of structures (Fig. 4).

\section{Lineament systems}

In total 1284 lineaments havebeen identified from Landsat TM images (pixel size $30 \mathrm{~m}$ ) at 1:100 000 scale (Fig. 3). Lineaments derived from both L andsat and aerial photographs have been grouped into systems based on their orientation. Fivemain lineament systems ( N - S, N N ESSW, ENE-WSW, ESE-WN W, and NNW-SSE) have been identified (Fig. 3; Table 1).

System 1 structures (green; Figs 3, 4) areoriented EN EW SW ( $\sim 060-090^{\circ}$ trend), and are pervasively distributed across the region. This system has a trend similar to the $N$ ordre Strømfjord and N ordre Isortoq fjords, and lies parallel to the regional basement fabric (foliation, gneissic banding, and shear zones; van G ool et al. 2002). N ote that as these lineaments may represent either faults or basement fabrics, care must betaken when analysing these quantitatively. In an attempt to minimise the amount of oversampling, only the most pronounced lineaments (e.g. most weathered out) that mark a distinct change in structure were mapped, while those that are clearly basement fabrics (i.e. those showing ductile features such as folds) were not.
System 2 lineaments (blue; Figs 3, 4) are N - S oriented (trend $\sim 350-010^{\circ}$ ), and often show sinistral offsets of pre existing structures (basement fabrics). This system can be traced from N ordre I sortoq to the northernmost part of the investigated area (Fig. 3), and previous investigations indicated that they may continue as far north as Aasiaat, D isko and N uussuaq (Japsen et al. 2002). Thefault zones areclosely spaced (100-500 m), and strike-slip separations of up to $30 \mathrm{~m}$ have been observed.

System 3 lineaments (red; Figs 3, 4) are N N W - SSE oriented (trend $\sim 140-170^{\circ}$ ). They are closely spaced (50$100 \mathrm{~m}$ ), and offsets of marble beds show net dextral separations in the order of 20-40 m (Fig. 4). This system is most pronounced in the N ordre Strømfjord shear zone, and less dominant in the $\mathrm{N}$ ordre I sortoq shear zone (see rose diagrams in Fig. 3).

System 4 lineaments (yellow; Figs 3, 4) areoriented N N ESSW (trend $\sim 010-040^{\circ}$ ) and are strongly developed in the $\mathrm{N}$ ordre Strømfjord shear zone region (camps 0 and 1 , Fig. 3). These structures show apparent sinistral strike slip separations of up to $400 \mathrm{~m}$ in the westernmost part of the study area. The spacing between them increases from approximately $500 \mathrm{~m}$ at the coast, to approximately $2 \mathrm{~km}$ farther inland. Thesamelineament directionswereencountered at camps 2 and 4, south of N ordre Strømfjord, where these structures are shorter and more discontinuous, possibly due to differences in rock type and fabric between the two areas.

System 5 lineaments (purple; Fig. 3) consist of $E-W$ to ESE-W N W (trend $\sim 090-120^{\circ}$ ) -oriented structures. The valleys that distinguish this system are generally $10-30 \mathrm{~m}$ wide and have a curved trend. This system appears to be mostly localised into two specific areas: the first of these lies in the fold belt south of Nordre Strømfjord (Fig. 3), and the second is located south of Sisimiut (Fig. 1).

\section{Relative timings}

Figure 4 shows an aerial photograph of an area around camp 1 where an apparent order of lineament development can be deduced. The oldest structures appear to be system 1 (green), and in this area these structures appear to be basement fabrics in the form of alternating layers of semipelite and marbleup to $100 \mathrm{~m}$ thick ( $\mathrm{H}$ enriksen et al. 2000). System 2 (blue) structures show sinistral offsets of these lithological layers, while system 3 structures (red) show dextral displacements. In Fig. 4, system 3 structures appear to dominantly cross-cut system 2 structures, but this is not always the case as in some areas the reverse is true (system 2 cross-cutting/displacing system 3). Asthere 
Table 1. Main characteristics for each fault system, identified from remote sensing and outcrop studies

\begin{tabular}{|c|c|c|c|}
\hline Lineament system & 0 rientation & Sense of movement & Comments \\
\hline System 1 & EN E-W SW & $\begin{array}{l}\text { - N ormal (dip-slip) } \\
\text { - Reverse (dextral oblique-slip) } \\
\text { - D extral and sinistral strike-slip }\end{array}$ & $\begin{array}{l}\text { - Basement-parallel to subparallel } \\
\text { - Multiple phases of movement }\end{array}$ \\
\hline System 2 & $\mathrm{~N}-\mathrm{S}$ & $\begin{array}{l}\text { - Sinistral strike-slip } \\
\text { - N ormal (dip-slip) }\end{array}$ & $\begin{array}{l}\text { - Closely spaced (100-500 m) } \\
\text { - Displacements range between } 0.2 \text { and } 30 \mathrm{~m} \text { for } \\
\text { individual faults } \\
\text { - May show an en échelon to irregular trend }\end{array}$ \\
\hline System 3 & N N W -SSE & $\begin{array}{l}\text { - D extral strike-slip } \\
\text { - N ormal (dip-slip and oblique-slip) }\end{array}$ & $\begin{array}{l}\text { - D ominant fracture/joint trend is associated with this } \\
\text { system } \\
\text { - Closely spaced ( } 50-100 \mathrm{~m}) \\
\text { - Marble layers show displacements in the order of } \\
20-40 \mathrm{~m}\end{array}$ \\
\hline System 4 & N NE-SSW & - Sinistral strike-slip & $\begin{array}{l}\text { - Major subvertical faults and fault zones } \\
\text { - Generally associated with wide (>50 m) valleys } \\
\text { - Exposed fault cores show complex fracture sets } \\
\text { associated with strike-slip movements }\end{array}$ \\
\hline System 5 & $\begin{array}{l}\text { E-W to } \\
\text { ESE-W N W }\end{array}$ & - D extral strike-slip & $\begin{array}{l}\text { - Localised to the fold belt south of N ordre Strømfjord } \\
\text { and north of the N ordre Isorto q shear zone } \\
\text { - Prominent structures at regional scale (i.e. from } \\
\text { Landsat and aerial photos) but not at outcrop } \\
\text { - Spatially associated with compressional faults (i.e. } \\
\text { system } 1 \text { reverse faults) }\end{array}$ \\
\hline
\end{tabular}

is evidencefor systems 2 and 3 mutually cross-cutting each other, and also because apparent movements are compatible with a conjugate system of strike-slip faults, it is possiblethat they arecontemporaneous. C ross-cuttingall other systems are the N N E-trending system 4 lineaments, suggesting that they are likely to be the youngest structures, or at least have experienced themost recent movements.

0 ther areas show a similar pattern of events, although somesystem 1 structures show evidencefor younger movements (reactivation?), especially in areas around camps 2 and 4. System 5 is not represented in Fig. 4 as it was not observed at camp 1. This system is marked by quite wide $(30-50 \mathrm{~m})$ valleys, thus making its displacements difficult to determine; however, as it is quite pronounced, it may be a more recent system.

\section{Field observations}

Four key areas were chosen for detailed fracture and fault analysis in the field (Fig. 3), based on their structural interest (i.e. their potential to enable all systems to be analysed) and accessibility. Thefirst objective of the field work was identification of the lineaments picked from the aerial photographs. In most cases field observations proved that the lineaments correspond to major fault structures, many of which areweathered out to leave gorges and river valleys (Fig. 5A-C). H owever, whilst many of the EN EW SW -oriented system 1 structures are faults, others also correspond to basement fabric features, such as strongly foliated zones, lithological contacts and shear zones (Fig. $5 \mathrm{D})$. Therefore care must be taken in any quantitative geometric or spatial analysis of this system.

After a regional reconnaissance from each field camp, detailed structural analysis was carried out. $\mathrm{N}$ inety outcrop locations were investigated in the four camps, distributed along the coast between $\mathrm{N}$ ordre I sortoq and just north of N ordre Strømfjord (Fig. 2). In total c. 1700 faults and fractures were measured and described.

\section{Fault geo metries}

A wide range of fracture orientations were observed (Fig. $6 \mathrm{~A})$, with dominantly N-S and N N W-SSE strikes and an overall mean fracture plane of $167 / 89 \mathrm{E}$. Various fault orientations can be separated out in the field (dominant trends are $\mathrm{N}-\mathrm{S}$ and $\mathrm{EN} \mathrm{E}-\mathrm{W} \mathrm{SW}$ ), showing a range of slip movements and shear senses (Fig. 6B-F). D ominant fault movements appear to be strikeslip ( $71 \%$ of faults recorded showstrikeslip movements), although extensional and compressional faults were also apparent. 

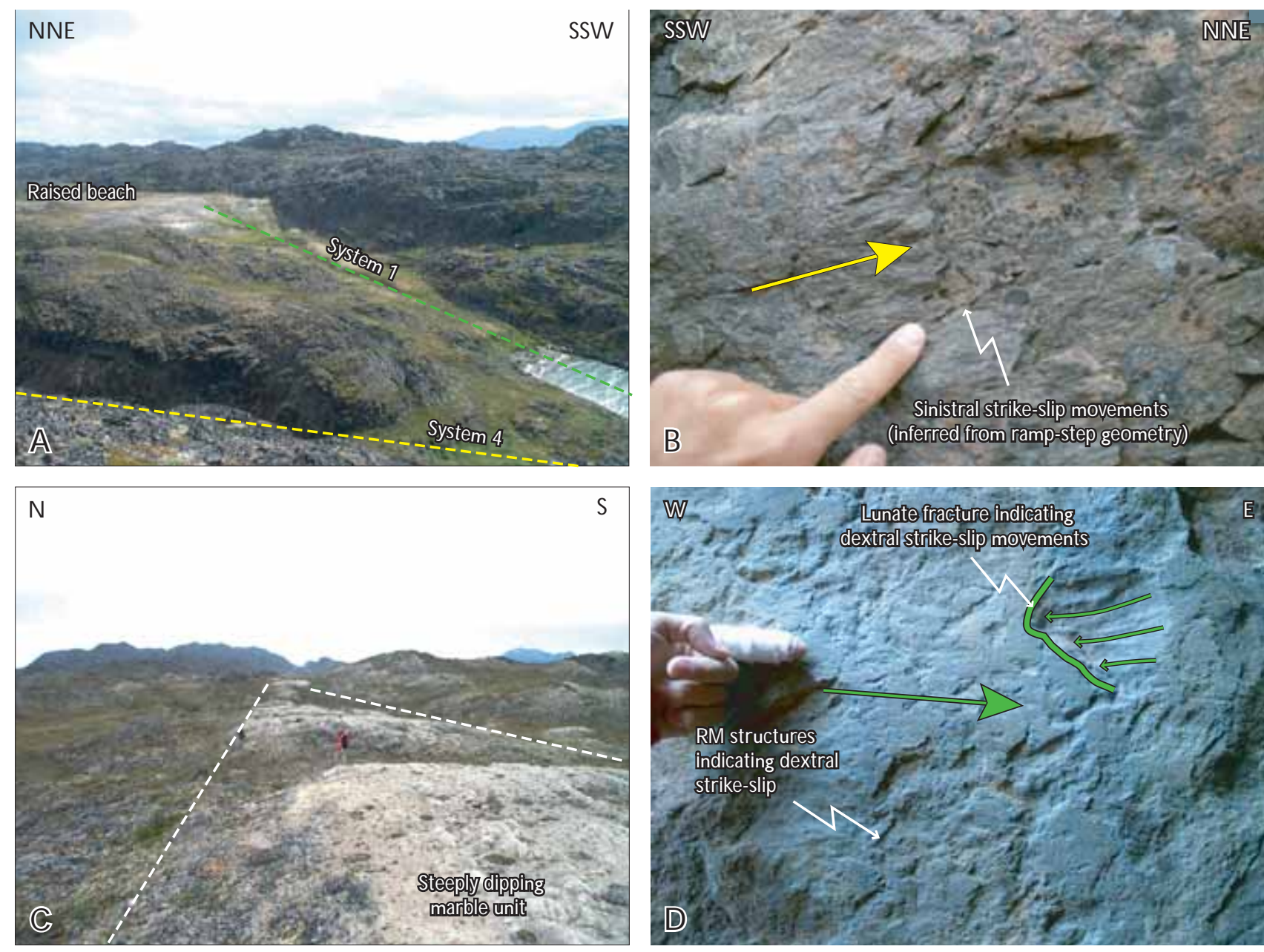

Fig. 5. Field identification of lineaments picked from Landsat and aerial photographs. A: Two major gorges/valleys trending EN E and N N E near camp 1; these correspond to major lineament systems 1 and 4, respectively. Fault core exposed within the N N E-trending stream bed (system 4) shows evidence for sinistral strike-slip faulting (Fig. 5B); fault movements on the EN E-trending basement-parallel valley (system 1) were not identified. B: Photograph of subhorizontal, sinistral strike-slip slickenlines observed within the fault core of the N N E-trending fault (system 4) identified in Fig. 5A. C: Some EN E-trending (system 1) lineaments correspond to basement fabrics such as steeply dipping (and tightly folded) marble units. D: 0 ther basement parallel lineaments, however, do show evidence for brittle fault movement, as identified in this EN E-trending fault core (fault movement criteria defined by secondary fracture indicators, i.e. RM and lunate fractures, outlined in Petit 1987).

A set of ENE-W SW-oriented faults (green planes/mean poles in Fig. 6) appear to reactivate strong basement fabrics in the Nordre Strømfjord and N ordre Isortoq shear zones. Thesefaults correspond to system 1 lineaments and exhibit various forms of fault movement (e.g. extensional, compressional and strike-slip; Fig. 6B-F). Faults corresponding to systems 2 ( $\mathrm{N}-\mathrm{S}$, blue), 3 (N N W -SSE, red) and 4 (N N E-SSW, yellow) can al so beeasily distinguished from the fault data in Fig. 6. H owever, lineament system 5 (E-W to ESE-W N W, purple) is not apparent. As pre viously discussed this system appears to be a more geographically localised system (i.e. local to areas south of the N ordre Strømfjord and N ordre Isortoq shear zones), and correspond to zones dominated by reverse fault move- ments (Fig. 6B) and a small number of ESE-trending dextral strike-slip faults (Fig. 6E).

Fault systems corresponding to lineament systems 2, 3 and 4 appear to consist of parallel fault zones separated by non-faulted, but generally strongly fractured rock. The fault zones range typically between 1 and $50 \mathrm{~m}$ in width (Fig. 5B) and consist of multiple parallel faults with variable spacing. These zones are commonly located in pronounced valleys and gorges (Fig. 5A), so characterisation of fault planes was often difficult as the valley floors are generally covered by recent sediment and vegetation. 
A

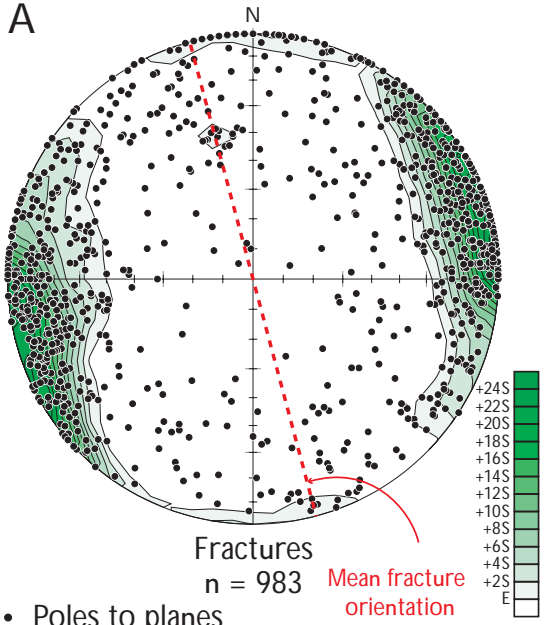

- Slickenlines

D

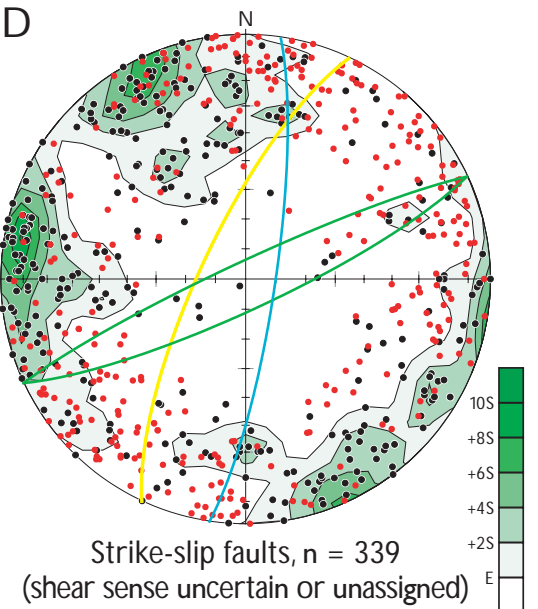

B

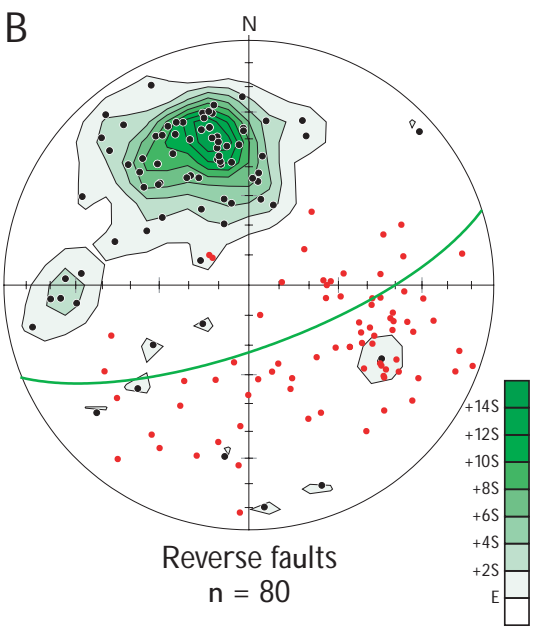

E

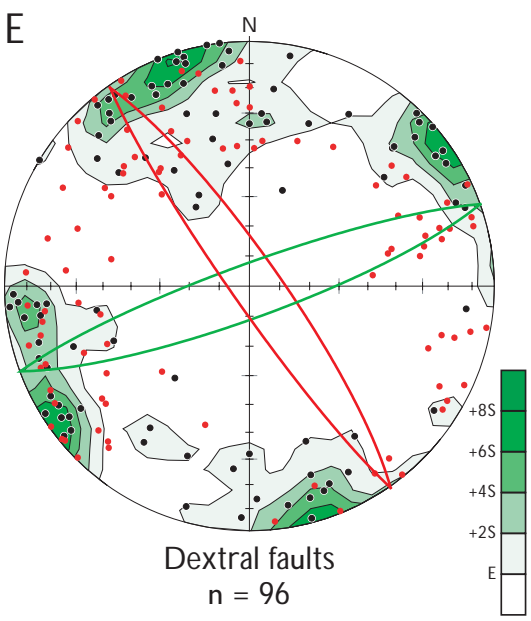

C

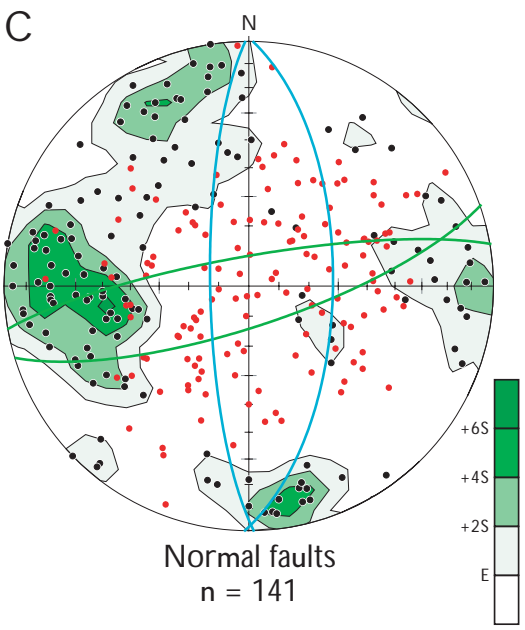

$\mathrm{F}$

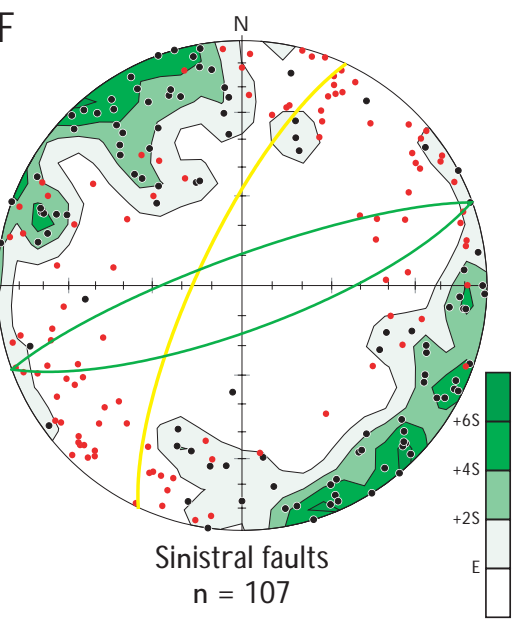

Fig. 6. Lower hemisphere, equal area stereographic projections of all fault and fracture data collected at camps 1, 2 and 4 (total number of measurements $=1746$ ). A: Fractures (i.e. planes showing no evidence for slip). B: Reverse faults. C: N ormal faults. D: Strike-slip faults with undetermined sense of movement. E: D extral strike-slip faults. F: Sinistral strike-slip faults. Black dots, poles to planes of fault and fracture surfaces. Red dots, slickenlines. M ean fault planes arealso shown, coloured according to lineament/fault systemsidentified in Fig. 3. Poles to fault and fracture surfaces are contoured using a $\mathrm{G}$ aussian weighting function; $\mathbf{n}$, number of measurements for each plot. In the labels, $\mathbf{E}$ corresponds to the background value (calculated as number of points/100), while $\mathbf{S}=$ standard deviations above this value.

\section{Fault kinematics}

In addition to the characterisation of the faults and fractures in terms of their trend and distribution, they can also be described according to their movement patterns (see Table 1). The nature and timing of tectonic events that areresponsiblefortheformation of thesefault-fracture systems is quite complex. Multiple directions of slickenlines on several fault surfaces indicate that many faults were either reactivated or that individual faults exhibit curved movement trajectories consistent with complex strain histories.

\section{Strike-slip faulting}

Strike-slip slickenlines account for $71 \%$ of those observed and were observed on all main fault geometries or systems. Multipleorientations of strike-slip faulting are common in wrench-dominated fault systems due to the development of Riedel, P and X shears (e.g. Woodcock \& Schubert 1994).

Basement parallel faults (system 1, green) show both dextral and sinistral movements (note, RM structures Petit 1987 - associated with R-shears suggest dextral movements on basement faults in Fig. 5D ). N N W-trending (system 3, red) faults appear to correspond to dextral movements. $\mathrm{N}$-trending faults (system 2, blue) appear to 


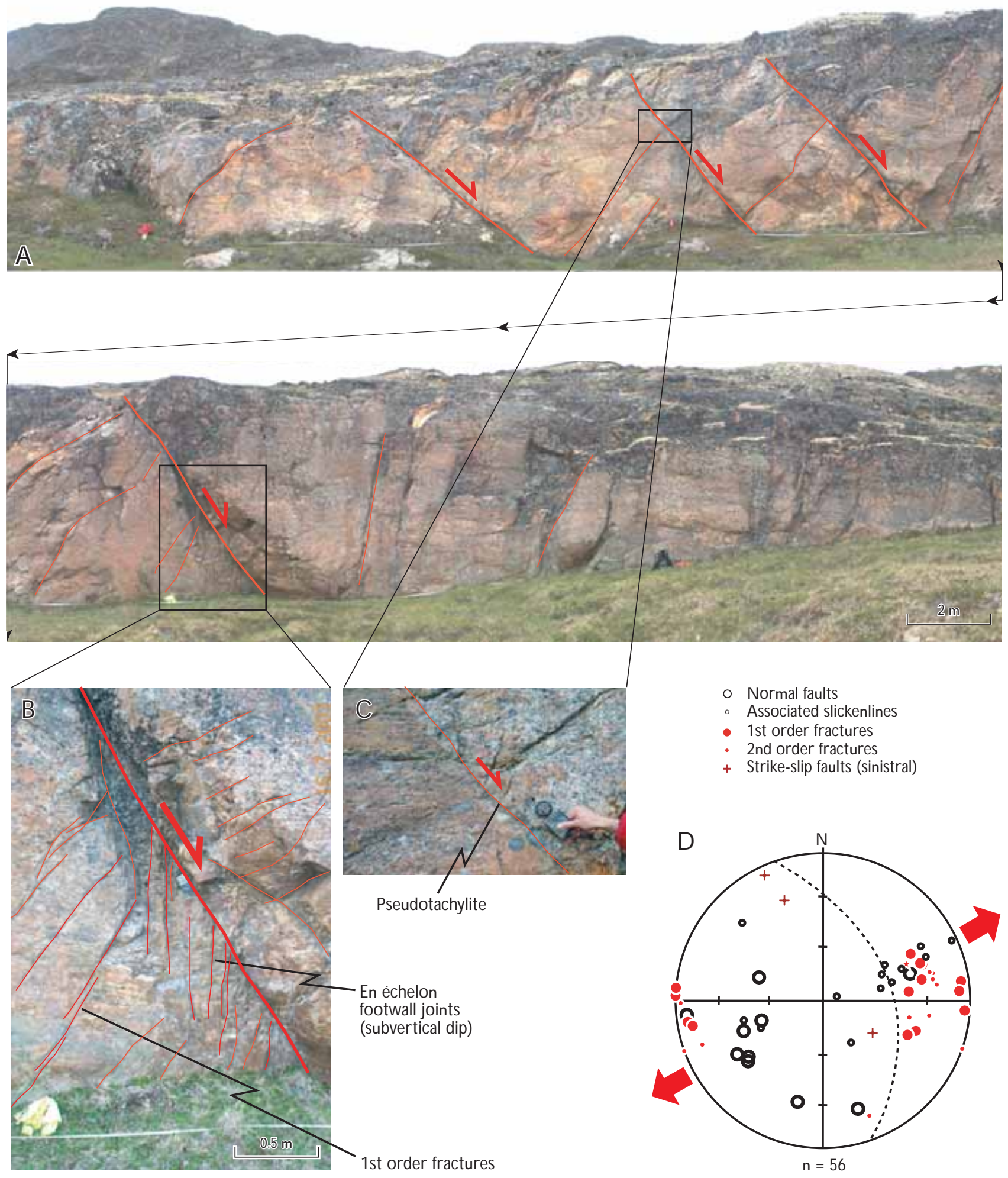

Fig. 7. A: Panoramic photograph showing exposures of a series of parallel EN E-dipping extensional faults, in the vicinity of camp 1. B and C: close-up photographs showing en échelon fracturing on the footwall of normal faults and pseudotachylitefault exposure in more detail. D : L ower hemisphere, equal area stereographic projection of poles to planes, and associated slickenlines, for faults and fractures observed at the outcrop of Fig. 7A. Fault orientations and kinematics suggest EN E-W SW extension as indicated by stress arrows (red); $\mathbf{n}$, number of measurements. 


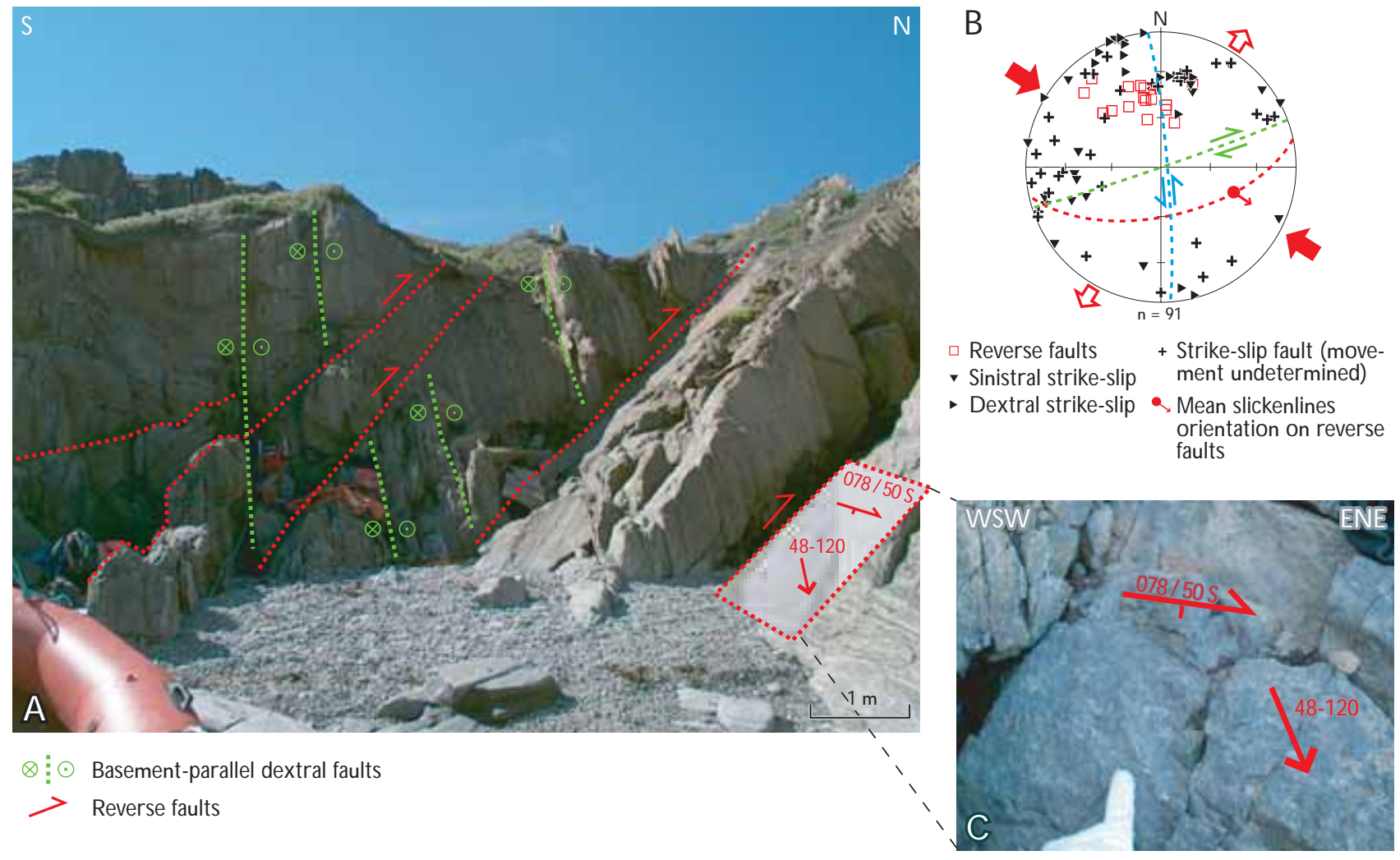

Fig. 8. A: Exposure of a localised set of reverse faults near camp 4. B: Lower hemisphere, equal area stereographic projections of poles to structures observed at the locality of Fig. 8A. Three dominant fault sets are apparent: basement parallel - i.e. EN E-trending - reverse and dextral strike-slip faults, and a set of sinistral faults oriented N-S (e.g. along the large rock face in shadow). Slickenline orientations and rel ative fault movements suggest ESE-W N W compression as indicated by stress arrows (red); $\mathbf{n}$, number of measurements. C: Photograph of surface of reverse fault, showing dextral-oblique slickenlines (mean slickenline orientation 45/120, see stereonet). $N$ ote that faults coloured in red here highlight thrust faults and do not refer to system 3 faults as in other figures.

show both dextral and sinistral movements, while N N Etrending faults (system 4, yellow) are sinistral structures (Fig. 6D-F).

\section{Extensional faulting}

Although all five fault systems show dominantly strikeslip movements, normal and oblique-slip components of displacement werealso recorded on somesets. Thesefaults appear to have two dominant orientations, N-S (system 2) and ENE-WSW (system 1; Fig. 6C). In some areas N N W -SSE (system 3) -oriented structures al so appear to be normal faults (Fig. 7), but these are not the dominant orientations in bulk analyses (Fig. 6). Field observations suggest that strike-slip movements post-date dip-slip.

\section{Compressional faulting}

Reverse faults (Figs 6B, 8) appear to be confined to areas close to camps 2 and 4 , and to be spatially associated with system 5 lineaments. These faults strike parallel or subparallel to basement structures (EN E-W SW to E-W, Fig. $6 \mathrm{~B})$ and exhibit dextral-oblique slickenlines, which plunge towards the ESE (Figs 6B, 8).

As these compressional or thrust faults are only found on the southern shore of $\mathrm{N}$ ordre Strømfjord and thenorthern shore of Nordre Isortoq (i.e. abutting against major basement shear zones) it is possible that these structures arethe result of local transpressional thrust faulting, which may be linked to steps in the en échelon sinistral fault system (system 4). Field observations suggest these compressional faults post-date most other fault and fractures. H owever, at camp 4, a N-S sinistral strike-slip fault appears to cross-cut these thrusts (Fig. 8B). 
Fractures and joints

A diversearray of fractureorientations was recorded. D ominant orientations vary from N W -SE through to N NESSW. The orientation of the mean plane is N N W - SSE. All fractures recorded showed no evidencefor shear move ment (i.e. rough surfaces and with no apparent offsets) and are thus interpreted as opening mode 1 fractures and suggesting extension directions varied from c. E-W to N ESW.

\section{Interpretation and discussion}

An overall summary of each of the fault systems identified through remote sensing (i.e. lineament mapping) and field studies is presented in Table 1. In this section we discuss the possible interpretations and implications of these observations.

\section{Fault development}

System 1 (EN E-W SW) faults and fractures appear to be the oldest structures, however multiple slip vectors and apparent fault movements suggest that there has been activity on this system during later tectonic episodes (note that system 1 faults are apparent in all stereoplots for all fault types, Fig. 6B-F). These lie parallel to the pre existing $N$ agssugtogidian basement fabric, which dates at $\mathrm{C}$. $1.8 \mathrm{Ga}$ (van G ool et al. 2002).

C ross-cutting relationships interpreted from analysis of aerial photographs suggest that the next systems to develop were systems 2 and 3 (Fig. 5). It is difficult to determine if one of these systems predates the other as mutually cross-cutting relationships can be seen; however, it does appear that system 3 is the more pervasive system and thus may be more recent.

Strike-slip movements and offsets on systems $2(\mathrm{~N}-\mathrm{S})$ and 3 (N N W -SSE) suggest that, if activeat the sametime, these would represent a strike-slip conjugate system. In such cases theinferred extension vector would trend EN EW SW, subparallel to system 1 foliation-parallel faults. This extension vector is also consistent with the dip-slip fault movements seen locally on these same fault systems.

These strike-slip movements appear to be preceded by dip-slip extensional movements. System $2(\mathrm{~N}-\mathrm{S})$ is the dominant extensional fault orientation in the area (Fig. $6 \mathrm{C}$ ), while somelocalities showed small populations where N N W -SSE-oriented extensional faults represent the preferred trend (e.g. Fig. 7). Thesefaults are indicative of E-
W to ENE-W SW extension. This extension cannot, however, explain the apparent basement-parallel (system 1) extensional faults, which suggest an apparent N N W -SSE extension. These EN E-trending normal faults have al so been observed in seismic interpretations and are thus important structures regionally.

These two extensional fault sets show a quadrimodal fault distribution, i.e. four sets of fault planes (Fig. 6C). If regarded as two separatefault sets, this geometry would suggest two separate extension directions ( $E-W$ and N N W -SSE); however an alternative to this is that these faultsformed contemporaneously under threedimensional strain (Reches 1983; N ieto-Samaniego \& Alaniz-Alvarez 1997). A s one set of normal faultstrends parallel to a pre existing plane of weakness (e.g. basement fabric) it is likely that basement reactivation played a role in the development of these faults, and that this has lead to formation of extensional faults oblique to the regional extension. The regional tectonic setting would fit with 3-D strain as the area borders the transfer zone between two extensional basins, i.e. is a transtensional deformation zone (D ewey 2002; D e Paola et al. 2005).

Geoffroyet al. (1998) recorded similar fault geometries and kinematicsfarther north in D isko and N uussuaq (Fig. 1). Their interpretation is that strikeslip and dip-slip faulting developed during a single tectonic episode of W SW EN E extension, which isin agreement with a model of 3-D transtensional strain.

As the stereoplots in Fig. 6 show, strike-slip faults are the dominant fault type in the area (as mentioned above, $71 \%$ of all faults measures are strikeslip) and these appear to post-date extensional movements. All fault systems show evidence for strike-slip movements. System 1 (EN E-W SW ) exhibits both dextral and sinistral senses of shear, systems 3 (N N W -SSE) and 5 (ESE-W N W ) show dextral shear, while systems 2 ( $N-S$ ) and 4 (N N E-SSW) are dominated by sinistral shear movements. System 4 faults (N N E-SSW ) appear to cross-cut all other fault sets, and are characterised by major fault zones (Fig. 5). These major sinistral strike-slip structures lie subparallel to the sinistral Ikermiut and U ngava fault zones that dominate the $D$ avis Strait offshore (Fig. 1). Assuming a N N Etrending sinistral wrench system for the study area, strike slip fault movements on each system appear to correlate closely with synthetic ( $R$ ) and antithetic ( $\left.R^{\prime}\right)$ Reidel shears, and also with synthetic $P$ and antithetic $X$ shears typical of a plane strain wrench tectonic regime (Fig. 9; Woodcock \& Schubert 1994).

Compressional faults appear to be relatively late structures (although cross-cut by $\sim \mathrm{N}-\mathrm{S}$-trending sinistral faults) and are localised in areas of strong basement fabric (i.e. 
Fig. 9. A: Diagram showing fault systems and their corresponding movements. B: Strain ellipse for a N N E-SSW $\left(\sim 010-190^{\circ}\right)$ -oriented sinistral wrench system, showing Riedel ( $\mathbf{R}$ and $\mathbf{R}^{\prime}$ ), $\mathbf{P}$ and $\mathbf{X}$ shears (Woodcock \& Schubert 1994). Also shown are the regional stress vectors ( $\boldsymbol{\sigma} \mathbf{1}$ and $\boldsymbol{\sigma} \mathbf{3}$ ). Systems 2 (sinistral) and 5 (dextral) correspond to $R^{\prime}$ and $R$ shears, while systems 1 (dextral) and 4 (sinistral) correspond to $P$ and $X$ shears. System 3 corresponds to normal fault sets in Fig. 9B; however, dominant movements on this system were dextral.

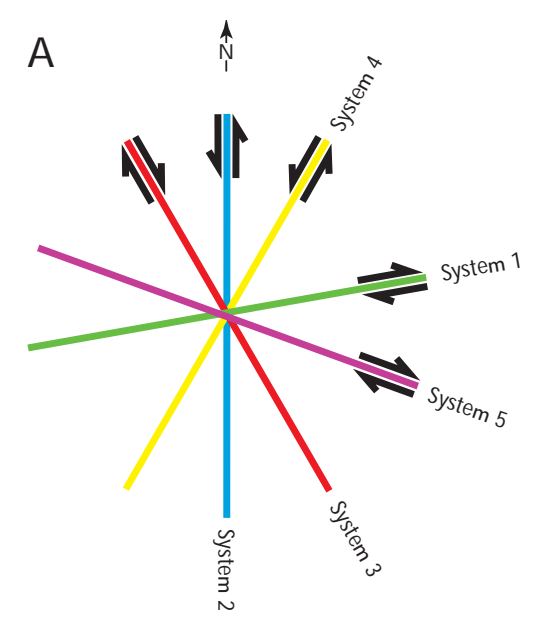

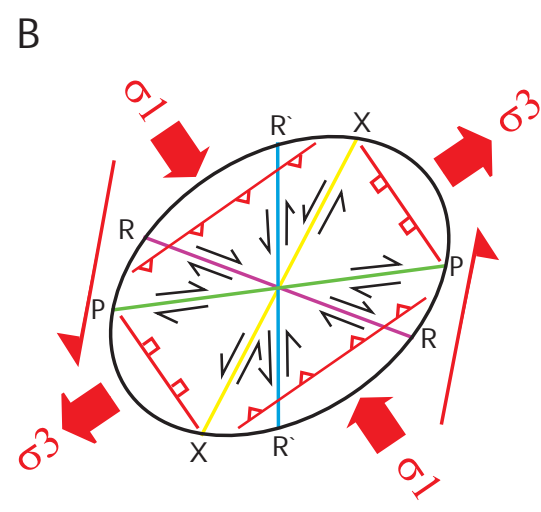

N N E-SSW $\left(10-15^{\circ}\right)$ wrench system: 55- $60^{\circ}$ extension, $145-150^{\circ}$ compression shear zones). These faults strike parallel to basement fabrics and indicate an oblique compression (from the ESE or SE; Fig. 8). 0 ffshore there is evidence for thrusting in a similar orientation along the Ikermiut fault zone (Fig. 1). Positiveflower structures have been identified (Chalmers \& Pulvertaft 2001) and are interpreted as inversion structures formed at a restraining bend during sinistral strikeslip along the Ungava transform fault, during the early Eocene (c. 54-49 M a, Chalmers\& Pulvertaft 2001). If trends of basement shear zones (outlined in Fig. 2) are continued alongstrikeoffshorethey appear to coincidewith these transpression zones within the lkermiut fault zone. It is possible that thrusts observed onshore have formed in a similar way to those offshore with basement shear zones acting as restraining bend structures, thus leading to localised compressional zones. Furthermore, slickenlines on the reverse faults suggest a compression from the ESE or SE (Figs 6B, 8), which is consistent with the compressional axisfor a sinistral wrench system (i.e. N E-SW extension and N W-SE compression; Fig. 9).

\section{Regional comparison and implications}

A key prerequisite for building tectono-stratigraphic models is being able to date each tectonic event. As all onshore exposures in this part of West Greenland are in Precambrian basement rocks, there are no stratigraphic markers for constraining thetiming of Phanerozoic tectonic events. Relative timing has been inferred from various cross-cutting relationships in the field and from lineament analysis, but is open to different interpretations. In the absence of age data that constrain the absolute age(s) of fault activity, comparisons with offshore models and with data collected in other onshore areas areused hereto infer ages for events in ourtectonic model (seeTable 2 for asummary).

\section{Regional onshore correlations}

Farthernorth intheregion of $D$ isko and $N$ uussuaq, on shore faulting episodes can bedated relative to the deposition of basaltic lavas and the sedimentary systems during $\mathrm{Cam}$ panian to Eocenetimes (G eoffroy et al. 1998; Storey et al. 1998; Chalmers et al. 1999; D am et al. 2000). Dam \& Sønderholm (1998), D am et al. (2000) and D am (2002) document at least three phases of faulting recorded in the sedimentary record prior to Paleocene volcanism. C retaceous- Pal eocene sediments on N uussuaq show distinctunconformities, with incised valleys and submarinecanyons, reflecting disturbances in early $\mathrm{C}$ ampanian, $\mathrm{M}$ aastrichtian and early Paleocene times. These unconformities and channels are thought to haveformed in response to structural movements associated with regional $\mathrm{NE}$-SW rifting (and also the arrival of the $\mathrm{N}$ orth Atlantic plume in the latter two cases).

${ }^{40} \mathrm{Ar} /{ }^{39} \mathrm{Ar}$ dating has revealed that volcanism commenced in West Greenland between 60.9 and $61.3 \mathrm{Ma}$ and that $80 \%$ of the Paleocene lava pile was erupted in less than $1 \mathrm{M} \mathrm{a}$ (Storey et al. 1998). These lavas show a distinct coastal flexure (G eoffroy et al. 1998, 2001; Larsen \& Pulvertaft 2000), presently expressed by seaward dipping basalt lavas. T hisflexure has an arcuate course, striking N W -SE in southern Svartenhuk $H$ alvø and northern $U$ bekendt Ejland, turning through $\mathrm{N}-\mathrm{S}$ in south-west $U$ bekendt Ejland to NE-SW in north-west N uussuaq and finally to $\mathrm{N}$-S in north-west Disko (Fig. 1; G eoffroy et al. 1998, 2001; Larsen \& Pulvertaft 2000). Numerous dykes cut these lavas (e.g. seefigs 4 and 5 in Larsen \& Pulvertaft 2000), and so do various fault sets ( $G$ eoffroy et al. 1998). Thetiming of thevariousphasesof volcaniceruption, dyke emplacement, and block faulting relativeto oneanother is still a matter of debate. G eoffroy et al. (1998) presented detailed structural evidence suggesting that fault and dyke intrusion on D isko took place during tilting of lava sys- 
Table 2. Proposed event stratigraphic model and apparent correlation with offshore events

\begin{tabular}{|c|c|c|c|}
\hline Event \# & Timing and event & O ffshore tectonic structures & O nshore tectonic structures \\
\hline $\begin{array}{l}5 \\
\text { (Yo ungest) }\end{array}$ & $\begin{array}{l}\text { Pliocene to } \\
\text { Pleistocene tilting }\end{array}$ & - Subsidence & $\begin{array}{l}\text { - Uplift? } \\
\text { - Possible reactivation of systems 1-4 as normal faults }\end{array}$ \\
\hline 4 & $\begin{array}{l}\text { Eocene Labrador } \\
\text { sea-flo or spreading } \\
\text { (Ungava system) }\end{array}$ & $\begin{array}{l}\text { - N - to N N E-trending sinistral } \\
\text { transverse fault system (U ngava } \\
\text { fault zone). } \\
\text { - Local transpressional and } \\
\text { transtensional faulting (e.g. } \\
\text { lkermiut fault zone) }\end{array}$ & $\begin{array}{l}\text { - Faults consistent with N N E-oriented sinistral wrench } \\
\text { system: N N E-trending (system 4) faults and } \\
\text { basement-parallel (system 1) faults active as antithetic X } \\
\text { and synthetic P shears } \\
\text { - Systems } 2 \text { (reactivation) and } 5 \text { active as Reidel shears } \\
\text { - Local transpressional thrust faulting observed near camps } \\
2 \text { and 4, associated with steep basement fabrics }\end{array}$ \\
\hline 3 & $\begin{array}{l}\text { Late Cretaceous to } \\
\text { early Paleocene } \\
\text { extension }\end{array}$ & $\begin{array}{l}\text { - N -trending faults in Davis Strait } \\
\text { (E-W extension) leading to } \\
\text { formation of the Sisimiut Basin } \\
\text { offshore }\end{array}$ & $\begin{array}{l}\text { - Systems } 1,2 \text { (and 3?) faults all active as extensional faults } \\
\text { during N E-SW to EN E-W SW extension } \\
\text { (3D strain)? }\end{array}$ \\
\hline 2 & $\begin{array}{l}\text { Early or middle to } \\
\text { late C retaceous } \\
\text { extension and } \\
\text { thermal subsidence }\end{array}$ & $\begin{array}{l}\text { - N W -trending normal faults in the } \\
\text { Labrador Sea (SW -N E extension) } \\
\text { - W SW -EN E faults bordering the } \\
\text { Sisimiut basin to the south were } \\
\text { active offshore during events } 2 \\
\text { and/or } 3\end{array}$ & - Uncertain? \\
\hline $\begin{array}{l}1 \\
\text { (O Idest) }\end{array}$ & $\begin{array}{l}\text { Proterozoic and later } \\
\text { localised reactivation }\end{array}$ & - Uncertain? & $\begin{array}{l}\text { - Possible system } 1 \text { EN E-W SW foliation-parallel faulting } \\
\text { prior to late Mesozoic? }\end{array}$ \\
\hline
\end{tabular}

tems. Geoffroy et al. (2001) then stated that N W-SEoriented, flexure-parallel dykes in southern Svartenhuk yield dates of around $54.6 \pm 0.6 \mathrm{M}$ a. This suggests that most of the coastal flexure is of Eocene age (or later?). Further evidence for this comes from north-west Nuussuaq where tilted lavas (Larsen \& Pulvertaft 2000) have been dated at $\sim 53 \mathrm{M} \mathrm{a}$ (Storey et al. 1998).

Systems 2 (N-S) and 3 (N N W - SSE) extensional faults in this study appear comparable to faults that cross-cut these Pal eocene basalt lavas (G eoffroy et al. 1998). Taking the dates outlined above for dyke emplacement which is believed to be associated with faulting, it would appear that our system 2 and 3 faults were active during Eocene times. Takingall theseonshoretectonictimingsinto account it would then appear that the faults observed may have been active from late $C$ retaceous ( $M$ aastrichtian) through to Eocenetimes(D am \& Sønderholm 1998; G eoffroy etal. 1998, 2001; C halmerset al. 1999; D am et al. 2000; Larsen $\&$ Pulvertaft 2000; Dam 2002).

$\mathrm{N}$ ormal fault orientations similar to systems $2(\mathrm{~N}-\mathrm{S})$ and 3 (N N W -SSE) occur in and around the N uussuaq basin (Fig. 1; Geoffroy et al. 1998; Chalmers et al. 1999) and are consistent with either EN E-W SW (G eoffroy et al. 1998) or E-W (Chalmers et al. 1999) extension. Chalmers et al. (1999) proposed that the N-S faults formed by E-W-oriented crustal extension, while associ- ated ESE-W N W faults formed as a consequence of reactivation of shear zones in the underlying basement. N ormal faults are dominantly $\mathrm{N}-\mathrm{S}$ onshore (Fig. $6 \mathrm{C}$ ), fitting with this model proposed by Chalmers et al. (1999). However, this implies that while Baffin Bay in the north and Labrador Sea in the south were undergoing EN E-W SW extension (deduced from dominant fault trends and earliestmagnetic anomalytrends, C halmers\& Pulvertaft2001), southern West $G$ reenland and the Nuussuaq basin were undergoing $\mathrm{E}-\mathrm{W}$ extension. A better explanation is that the $D$ avis Strait at this time (i.e. prior to the onset of seafloor spreading) lay in a transfer/step-over zone between two extensional basins, and that it was strongly influenced by basement fabrics such that this region experienced complex 3-D strain associated with regional EN E-W SW extension (Fig. 10). 0 nshorenormal fault sets form a quadrimodal fault distribution (four sets of fault planes, Fig. 6C) consistent with 3-D strain.

This faulting is then subsequently dissected by $\mathrm{N}-\mathrm{S}$ (system 2) and N NE-SSW (system 4) -oriented faults during the Eocene (Chalmers et al. 1999). The Itilli fault zone (Fig. 1) is one such N N E-SSW-oriented structure cutting through north-west N uussuaq. This fault zone appears to be a left-lateral splay from the northern extension of the U ngava fault zone in the $\mathrm{D}$ avis Strait (C halmers et al. 1999). 
STAGE 1:

Late C retaceous-Paleocene extension (N E-SW to EN E-SSW ).

Pre-existing basement anisotropy ( $\mathrm{N}$ agssugtoqidian

orogenic belt) appears to influence fault patterns in the

D avis Strait. Possible strain partitioning between basement-

parallel and $\mathrm{N}$-S-trending normal faults.

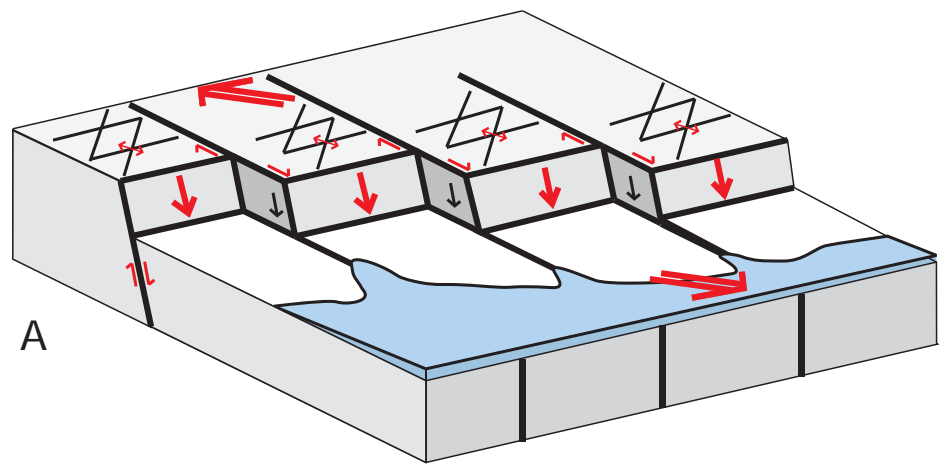

STAGE 2:

N N E-trending Eocene sinistral wrench system (NE to ENE

extension, SE to SSE compression) reactivating earlier

extensional faults and basement-parallel structures (e.g.

thrust faults at camp 4, and the lkermiut fault zone).

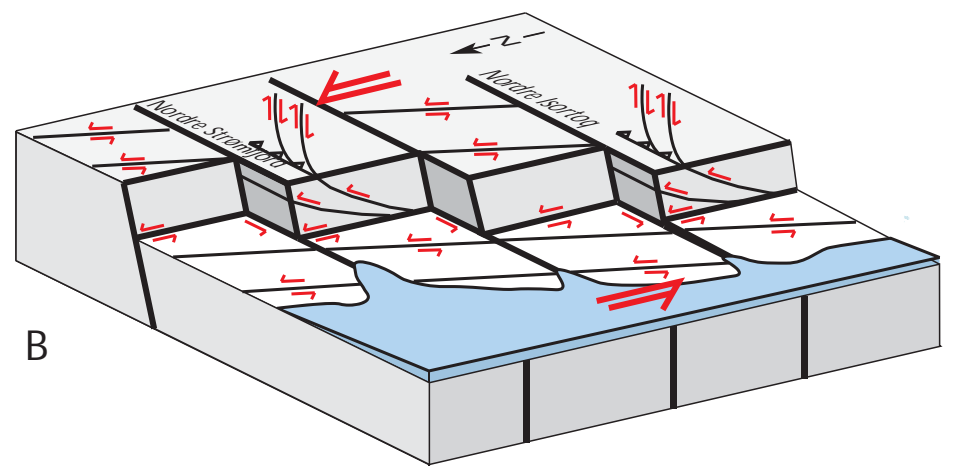

B

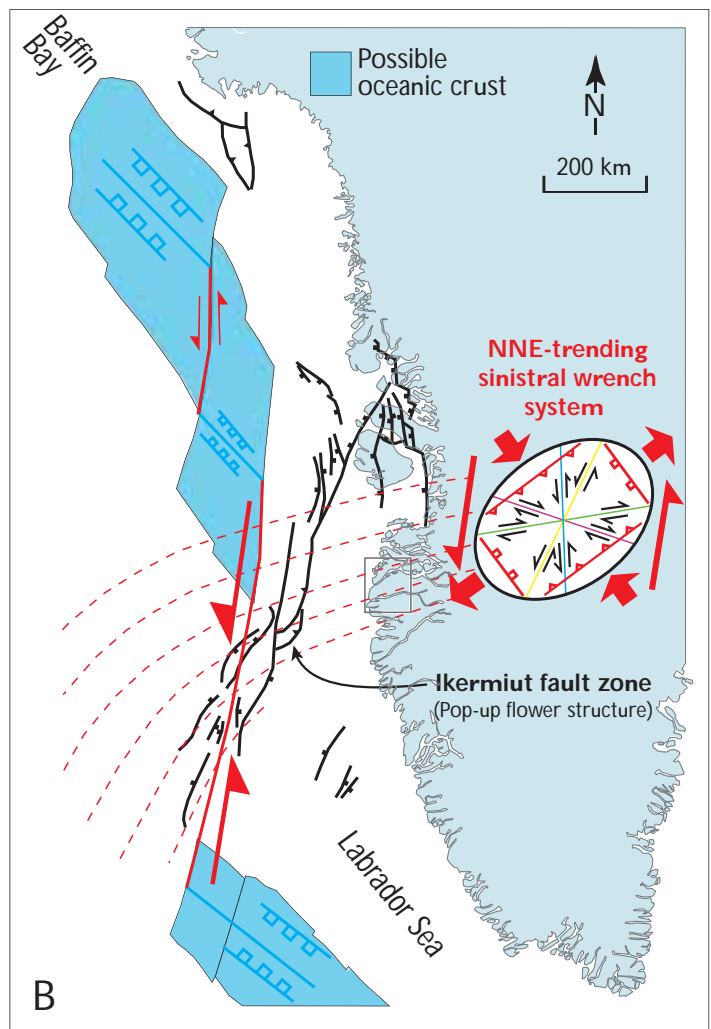

Fig. 10. Proposed two-stage tectonic model for the tectonic evolution of upper M esozoic - Cenozoic extension within the $\mathrm{N}$ agssugtogidian orogen. Stage 1(A): N - and EN E-trending normal faults and dextral basement reactivation due to EN E-W SW extension. Stage 2 (B): N - and N NE-trending sinistral strike-slip faulting, and associated strike-slip wrench tectonic systems, with compressional structures (reverse faults) forming in zones of basement anisotropy (e.g. shear zones). Block diagrams show schematic cartoons outlining fault patterns observed onshore, while maps show the regional context, based on correlations between onshore and offshore fault structures. 
Correlation with fault structures offshore

Fault patterns offshore in the $D$ avis Strait exhibit similar c. N-S and EN E-W SW dominant orientations. The south and east bounding faults to the Sisimiut basin strikeEN EW SW and N-S respectively (Fig. 1). Significantly, the southern margin of the Sisimiut basin is coincident both in orientation and location with a major basement shear zone (theN ordre Isortoq shear zone), and is likely to have exerted a similar structural control to that interpreted for onshore. Block faulting has been dated via drilling as having taken place between the late $C$ ampanian and late Pale ocene (Christiansen et al. 2001; D al hoff et al. 2003), indicating that these extensional faults are of similar age to those associated with valley incision on $\mathrm{N}$ uussuaq and north D isko (Dam \& Sønderholm 1998; D am et al. 2000; Dam 2002).

The Ungava fault zone with its associated fault systems (e.g. thel kermiut fault zone) is the most prominent structure in the Davis Strait (Chalmers \& Pulvertaft 2001). This N N E-SSW -oriented structure is interpreted as a transform fault zone showing sinistral shear, and has been linked to theltilli fault zone (Fig. 1; C halmers et al. 1999). System 4 (N N E-SSW) faulting onshore, around N ordre Stromfjord, is consistent with latesinistral strike-slip movements, and it is reasonable to suggest that this system is of similar age. Asalready discussed, offshore evidencefor sinistral strike-slip movements can be seen in the I kermiut faultzoneon thewestern margin of theSisimiutbasin (Chalmers \& Pulvertaft 2001) where transpressional thrusts (similar to compressional flower structures modelled in D ooley et al. 1999) appear to have formed in the restraining bend of a strike-slip fault (see fig. 6 of Chalmers \& Pulvertaft 2001). These thrusts cut early Eocene mudstones, but are overlain by late Eocene sediments, providing further evidence for timing of these movements. This sinistral shear is thus a consequence of left-lateral movement of the $C$ anadian platerelative to the $G$ reenland plate along the Ungava transform system during sea-floor spreading in the Labrador Sea (Fig. 1).

\section{Evidence for neotectonic faulting?}

Chalmers (2000) presented evidence for $\mathrm{N}$ eogene uplift in offshore areas of central West G reenland, while recent onshore topographic and apatite fission-track data analysis has identified similar N eogene activity (J apsen et al. $2002,2005)$. A common observation in this field area is the presence of raised beaches and palaeoshorelines, up to elevations $30 \mathrm{~m}$ above present sea levels (Fig. 5A). They are probably the result of isostatic readjustment following the removal of Pleistocene ice load. Topographically, the region appears to be divided into blocks, split by EN Etrending fjords and N N E-trending escarpments (Fig. 2C). These must be quite recent features as they have not been eroded during glacial activity (and may in fact bea consequence of it). The trend of system 4 faults (and also locally those of system 2) is generally parallel to the pronounced N N E-trending escarpment from N ordre Isortoq to N ordre Strømfjord onshore, and also to a similarly trending scarp near offshore (identified in bathymetry maps), and it is possible that these faults have been reactivated as normal faults during a recent tectonic event. This conjecture still needs to be verified, as the main escarpments were not studied in detail during our field work.

\section{Summary}

The observed fault and fracture systems reflect a brittle tectonic history that is ultimately related to far-field plate movements, uplift and basin formation. The development of M esozoic to Cenozoic basins offshore West Greenland appears to be strongly controlled by faults. Therefore, knowledge of thefracture systems in the exposed Precambrian basement provides a valuable insight into fault ge ometries and kinematics during the development of offshore basins and potential hydrocarbon reservoirs. It al so provides insights into the possible influence of basement reactivation.

Several possible tectonic-event models may be constructed for this region given the lack of definite ages for structures. Table 2 shows a basic summary of the relative timings of fault systems identified in this study relative to regional offshore tectonic models, while Fig. 10 presents a model for fault development based on the observations and correlations made in this study. The absolute timing of the fault activity onshore, as deduced from correlation to other fault systems with known ages, needs to betested by dating of fault rock samples. A simpletwo-stage model has been outlined to explain the complex fault patterns exhibited in onshore exposures of the central $\mathrm{N}$ agssugtoqidian orogen (Fig. 10).

The brittle tectonic evolution of the region appears to be dominated by NE-SW extension, which is consistent with theopening of the Labrador Sea and Baffin Bay. O nly slight variations in the regional stress field are required to account for the diversity of fault orientations. According to Chalmers \& Pulvertaft (2001) there was a $15^{\circ}$ counter 
clockwise rotation in spreading direction between thePaleoceneand theEocenein the Labrador Sea asopening started between Greenland and Europe, which is consistent with the two-stage model outlined in Fig. 10. In the early stages of opening, faulting was dominated by extensional structures (under 3-D strain conditions), favouring an EW to EN E-W SW extension (Fig. 10A); however, as the Ungava transform fault developed, faulting became more wrench dominated (2-D plane strain), and suggests N ESW extension (Fig. 10B). Variationsin fault geometry reflect these changes in the regional stress field. H owever, the influence of basement structure also appears to have played an important role throughout (e.g. extensional faults not normal to the extension direction, and theapparent localised compressional zones associated with intense basement fabrics). Although most faults observed onshore trend highly obliquely to basement fabrics, fault patterns do appear to vary in areas of intense pre-existing structure (such as the N ordre Strømfjord and N ordre Isortoq shear zones) which suggest that the fabrics within the N agssugtogidian orogen may have had some influence on the fault complexity of the Davis Strait.

The conclusions from this study show that the fault patterns and sense of movement on faults onshore reflect the stress fields that govern the opening of the Labrador Sea- D avis Strait - Baffin Bay seaway, and that the wrench couple on the Ungava transform system played a dominant role in the development of the onshore fault patterns.

\section{Acknowledgements}

The authors would like to thank BP (N orway) and Statoil (UK) for providing additional funding for this field research, and to NERC for funding R.W.W.'S Ph.D. re search (NER/S/S/2001/06740). Thorough and insightful reviews from S. Bergh and T.C.R. Pulvertaft and additional help from the latter concerning numerous details are greatly appreciated. The bulletin editors, A.A. G arde and F. Kalsbeek, are also thanked for their helpful and encouraging comments.

\section{References}

Bonow, J.M . 2004: Palaeosurfaces and palaeovalleys on N orth Atlantic previously glaciated passive margins - reference forms for conclusions on uplift and erosion. Ph.D. thesis. Thesis in G eography with Emphasis on Physical G eography 30, 17 pp. +4 articles. Stockholm University, Sweden.

Butler, R.W.H., H oldsworth, R.E. \& Lloyd, G.E. 1997: The role of basement reactivation in continental deformation. Journal of the Geological Society (London) 154, 69-71.

Chalmers, J.A. 2000: 0 ffshore evidence for $N$ eogene uplift in central West G reenland. G lobal and Planetary Change 24, 311-318.

Chalmers, J.A. \& Laursen, K.H . 1995: Labrador Sea: the extent of continental crust and thetiming of the start of seafloor spreading. $M$ arine and Petroleum G eology 12, 205-217.

Chalmers, J.A. \& Pulvertaft, T.C.R. 2001: D evelopment of the continental margins of the Labrador Sea: a review. In: Wilson, R.C.L. et al. (eds): N on-volcanic rifting of continental margins: a comparison of evidence from land and sea. Geological Society Special Publication (London) 187, 77-105.

Chalmers, J.A., D ahl-Jensen, T., Bate, K.J. \& W hittaker, R.C. 1995: $\mathrm{G}$ eology and petroleum prospectivity of the region offshore southern West G reenland. Rapport Grønlands G eologiske Undersøgel se 165, 13-21.

Chalmers, J.A., Pulvertaft, T.C.R., M arcussen, C. \& Pedersen, A.K. 1999: N ew insight into the structure of the N uussuaq basin, central West G reenland. M arine and Petroleum G eology 16, 197-224.

Chian, D . \& Louden, K.E. 1994: The continent-ocean crustal transition across the southwest G reenland margin. Journal of Geophysical Research 99, 9117-9135.

Christiansen, F.G., Bojesen-Koefoed, J.A. \& Chalmers, J.A. 2001: Pe troleum geological activities in West $G$ reenland in 2000. G eology of Greenland Survey Bulletin 189, 24-33.

D alhoff, F., Chalmers, J .A., G regersen, U ., N øhr-H ansen, $\mathrm{H}$., Rasmussen, J.A. \& Sheldon, E. 2003: M apping and facies analysis of Pale ocene - Mid-Eocene seismic sequences, offshore southern West G reenland. M arine and Petroleum G eology 20, 935-986.

D am, G. 2002: Sedimentology of magmatically and structurally controlled outburst valleysalong rifted volcanic margins: examplesfrom the N uussuaq basin, West G reenland. Sedimentology 49, 505-532.

Dam, G. \& Sønderholm, M. 1998: Sedimentological evolution of a fault-controlled early Paleocene incised-valley system, Nuussuaq Basin, W est Greenland. In: Shanley, K.W. \& McC abe, P.J. (eds): Relative role of eustasy, climate, and tectonism in continental rocks. Society of E conomic Paleontologists and M ineralogists Special Publication 59, 109-121.

D am, G ., N øhr-H ansen, H ., Pedersen, G .K . \& Sønderholm, M . 2000: Sedimentary and structural evidence of a new early $C$ ampanian rift phase in the N uussuaq Basin, West G reenland. C retaceousR esearch 21, 127-154.

D e Paola, N., H oldsworth, R.E., M cC affrey, K.J.W. \& Barchi, M.R. 2005: Partitioned transtension: an alternative to basin inversion models. Journal of Structural G eology 27, 607-625.

D ewey, J.F. 2002: Transtension in arcs and orogens. International Ge ology Review 44, 402-439. 
Dooley, T., M cClay, K.\& Bonora, M . 1999: 4D evolution of segmented strike-slip fault systems: applications to N W Europe. In: Fleet, A.J. \& Boldy, S.A.R. (eds): Petroleum geology of Northwest Europe, Proceedings of the 5th Conference, 215-225. London: G eological Society.

Escher, J.C. \& Pulvertaft, T.C.R. 1995: Geological map of G reenland, 1:2 500 000. Copenhagen: $G$ eological Survey of Greenland.

Geoffroy, J., G élard, J.P., Lepvrier, C. \& Olivier, P. 1998: The coastal flexure of Disko (West Greenland), onshore expression of the 'oblique reflectors'. Journal of the $\mathrm{G}$ eological Society (London) 155, 463-473.

Geoffroy, J. et al. 2001: Southeast Baffin volcanic margin and the N orth American - G reenland plate separation. Tectonics 20, 566-584.

Henriksen, N ., H iggins, A.K., Kalsbeek, F. \& Pulvertaft, T.C.R. 2000: $G$ reenland from Archaean to $Q$ uaternary. D escriptive text to the geological map of Greenland, 1:2500 000. Geology of G reenland Survey Bulletin 185, $93 \mathrm{pp}$.

Holdsworth, R.E., Butler, C.A. \& Roberts, A.M . 1997: The recognition of reactivation during continental deformation. Journal of the Geological Society (London) 154, 73-78.

Japsen, P., Bonow, J., Klint, K.E.S. \& Jensen, F.K. 2002: N eogene uplift, erosion and resedimentation in West Greenland. Field report summer 2002. Danmarks og Grønlands G eologiske U ndersøgelse Rapport 2002/71, 114 pp.

Japsen, P., G reen, P.F. \& C halmers, J.A. 2005: Separation of Palaeogene and $N$ eogene uplift on Nuussuaq, West $G$ reenland. Journal of the Geological Society (London) 162, 299-314.

Larsen, J.G. \& Pulvertaft, T.C.R. 2000: The structure of the Cretaceous-Pal aeogene sedimentary-vol canic area of Svartenhuk H alvø, central West Greenland. G eology of Greenland Survey Bulletin 188, $40 \mathrm{pp}$.

M arker, M ., M engel, F., van G ool, J. and field party 1995: Evolution of thePal aeoproterozoic N agssugtogidian orogen: D LC investigations in West Greenland. Rapport Grønlands G eologiske Undersøgelse 165, 100-105.

M cClay, K.R. 1987: T he mapping of geological structures (G eological Society of London handbook), 161 pp. London: John W iley and Sons.

Nieto-Samaniego, A.F. \& Alaniz-Alvarez, S.A. 1997: 0 rigin and tectonic interpretation of multiplefault patterns. Tectonophysics $\mathbf{2 7 9}$, 197-206.

Petit, J.-P. 1987: C riteria for the sense of movement on fault surfaces in brittle rocks. Journal of Structural G eology 9, 597-608.

Ramberg, H . 1949: On the petrogenesis of the gneiss complexes between Sukkertoppen and Christianshaab, West Greenland. M eddelelser fra Dansk G eologisk Forening 11, 312-327.

Reches, Z. 1983: Faulting of rocks in three dimensional strain fields. II. Theoretical analysis. Tectonophysics 95, 133-156.

Storey, M ., D uncan, R.A., Pedersen, A.K., Larsen, L.M . \& Larsen, H .C. 1998: ${ }^{40} \mathrm{Ar} /{ }^{39} \mathrm{Ar}$ geochronology of the West $\mathrm{G}$ reenland Tertiary volcanic province. Earth and Planetary Science Letters 160, 569-586.

Taylor, B., Crook, K. \& Sinton, J. 1994: Extensional transform zones and oblique spreading centres. Journal of $G$ eophysical Research 99(B10), 19707-19718.

van Gool, J.A.M ., Connelly, J.N ., M arker, M . \& M engel, F.C. 2002: TheN agssugtogidian orogen of West $G$ reenland: tectonic evolution and regional correlations from a West $\mathrm{G}$ reenland perspective. Canadian J ournal of Earth Sciences 39, 665-686.

Whittaker, R.C. 1995: A preliminary assessment of the structure, basin development and petroleum potential offshore central W est Greenland. O pen File Series Grønlands Geologiske U ndersøgelse 95/9, 33 pp., 6 maps.

Woodcock, N.H \& \& Schubert, C. 1994: Continental strike-slip tectonics. In: H ancock, P.L. (ed.): Continental deformation, 251-263. 0 xford: Pergamon Press. 